The definitive version is available at www.blackwell-synergy.com

(http://onlinelibrary.wiley.com/doi/10.1111/j.1475-4754.2006.00254.x/abstract)

DOI: $10.1111 /$ j.1475-4754.2006.00254.x

(http://dx.doi.org/10.1111/j.1475-4754.2006.00254.x)

\title{
CHEMICAL CHARACTERIZATION OF TIN-LEAD GLAZED POTTERY FROM THE IBERIAN PENINSULA AND THE CANARY ISLANDS: INITIAL STEPS TOWARD A BETTER UNDERSTANDING OF SPANISH COLONIAL POTTERY IN AMERICAS
}

Javier G. Iñañez ${ }^{1,2}$, Robert J. Speakman ${ }^{1}$, Jaume Buxeda i Garrigós ${ }^{2}$, Michael D. Glascock $^{3}$

Archaeometry, 51, 546-567 (2009) 
CHEMICAL CHARACTERIZATION OF TIN-LEAD GLAZED POTTERY FROM

THE IBERIAN PENINSULA AND THE CANARY ISLANDS: INITIAL STEPS TOWARD A BETTER UNDERSTANDING OF SPANISH COLONIAL POTTERY IN AMERICAS

Javier G. Iñañez ${ }^{1,2}$, Robert J. Speakman ${ }^{1}$, Jaume Buxeda i Garrigós ${ }^{2}$, Michael D. Glascock $^{3}$

1. Museum Conservation Institute, Smithsonian Institution, Suitland, MD 20746-2863 (USA)

2. Cultura Material i Arqueometria de la Universitat de Barcelona (ARQUB), Facultat de Geografia i Història, Universitat de Barcelona, c/ Montalegre, 6-8, 08001, Barcelona (Catalonia, Spain)

3. Research Reactor Center, University of Missouri, Columbia, MO 65211 (USA)

\section{ABSTRACT}

Majolica pottery was the most characteristic tableware produced during the Medieval and Renaissance periods. Because of the prestige and importance attributed Spanish majolica was imported in vast quantities to the Americas during the Spanish Colonial period. Nowadays, Majolica pottery serves as an important horizon marker at Spanish colonial sites. A study of Spanish majolica was conducted on a set of 186 samples from the 10 primary majolica production centers on the Iberian Peninsula and 22 sherds from two early colonial archaeological sites from the Canary Islands. The samples were 2 
analyzed by instrumental neutron activation analysis (INAA), and the resulting data were interpreted using an array of multivariate statistical procedures. Our results show a clear discrimination among different production centers allowing a reliable provenance attribution of the sherds from the Canary Islands.

\section{KEYWORDS}

Majolica, Neutron Activation Analysis, Provenance, Multivariate Statistics, Iberian Peninsula, Canary Islands

\section{INTRODUCTION}

Majolica is an earthenware pottery characterized by a creamy light-buff colored ceramic body and an opaque white tin-lead glaze covering the entire outer surface of the vessel. The most characteristic feature of majolica pottery lies in the metallic-oxide decorations that are applied on top of the opaque white glaze coat. The opaque white glaze is composed of sand (e.g., quartz) and lead, which serves as a flux to decrease the temperature needed for melting $\mathrm{SiO}_{2}$. The glaze is opacified with particles of tin oxide $\left(\mathrm{SnO}_{2}\right)$ and also by the action of extant quartz and feldspar inclusions. These inclusions, and the bubbles that result from the firing process, absorb, scatter, and/or reflect incident light, thereby giving the transparent glaze a white appearance. Due to this opacity, decoration is normally applied to the outer surfaces of the glaze coat (Iñañez, 2007; Kingery and Aronson, 1990; Molera et al., 1999; Tite et al., 1998). 
By the fifteen but specially during the sixteenth century, Spanish majolica production flourished as Italian-influenced decorative styles diffused into the Iberian Peninsula. Consequently, black and especially green motifs-colors sometimes associated with Islamic ceramic traditions—-were progressively replaced with blue patterns-although it was used in the precedents centuries is now when blue really flourishes over the rest-, sometimes mixed with other colors, especially yellow. By the end of the sixteenth and seventeenth centuries, majolica polychrome was being produced throughout the Iberian Peninsula. At the same time the production of lusterware declined, both in quantity and quality. Some of the most characteristic and important production centers from this period were Barcelona, Reus, Vilafranca del Penedès and Lleida in the Catalan area; Manises in the Valencian area; Muel and Villafeliche in Aragon; and Talavera de la Reina, Puente del Arzobispo and Sevilla in the Central and South Spain respectively (Figure 1). As the commercial trade between the Americas and Europe increased, the port of Seville became the primary port of trade for Spain. The increased importance of Seville occurred because this city's inland fluvial port protected from pirates attacks served as both the departure point and the final destination for most of the Spanish galleons that traded with the Americas in the so called "Carrera de Indias". In order to supervise the traffic of goods, a bureau of trade was established in 1503, called Casa de la Contratación, only eleven years after the discovery of the Americas. The Casa de la Contratación had, for more than 200 years (1503-1717), its primary office in the city of Seville. Whereas, Seville became the primary production center for majolica exported outside of Spain, Talavera became the most important production center for majolica consumed within the Castillian Kingdom becoming the official supplier of royal tableware. Additionally, the Canary Islands represented the key stopping point for Spanish access to the Americas. The Canary Islands were a required stopover for 4 
Spanish trade with the Americas because of the need to take advantage of the ocean currents and Alisios (Trade) Winds that blow directly to the Caribbean from the eastern Atlantic. Moreover, the Canary Islands signified, for all the Spanish ships, the last geographic region controlled by the Spaniards before starting their long open-sea voyage. The Canary Islands also were a required stop for legal reasons in which the Castilian Kingdom established a rigid control over the trade of items to the New World.

La Cueva Pintada is one of the most important Prehispanic settlement in Gran Canaria island, placed in the present city of Gáldar. The native settlement, called Agaldar, had a continue occupation from the $6^{\text {th }}$ to the $16^{\text {th }}$ century, when it was definitely abandoned after the Spanish conquest. Agaldar was the capital of the main indigenous chiefdom of the island of Gran Canaria and after the conquest it was one of the first Spanish settlements. The name of La Cueva Pintada comes from the exceptional Prehispanic artificial cave, found in the site in 1862 , which was excavated in the tuft and painted with geometrical motifs by Gran Canarian aborigines. In the $18^{\text {th }}$ century the area where this site is placed was used as crops until 1970's, when the planned archaeological and conservation works started (Onrubia et al., 2004). On the other hand, the ancient convent of San Francisco at Las Palmas de Gran Canaria (Gran Canaria Island) was built at the end of the $15^{\text {th }}$ century. It is one of the most important historical sites, because represents the earliest foundation of Franciscan order in the island during the Canary Islands Conquest process. The convent remained active until 1835, when the Franciscans were forced to leave it as a result of a general confiscation ordered by the Spanish Government known as the Mendizabal's confiscation. After being used by the Army, the building was definitely abandoned halfway through the $20^{\text {th }}$ century. In 1992 the Archaeological section of the Museo Canario de Las Palmas de Gran Canaria started 5 
the archaeological excavation of the San Francisco's convent remains, where a large quantity of majolica pottery, not only Spanish but also Italian and Portuguese, was recovered. This fact clearly points to the role played by the Canary Islands in the trade network between Europe and America (Sosa Suárez, 2002).

In this paper, we summarize the results from compositional analysis of 186 majolica sherds obtained from the 10 primary production centers located on the Iberian Peninsula used as reference groups and their comparison with a sample of 22 majolica sherds obtained from two early colonial sites on the Canary Islands: la Cueva Pintada (Gáldar) and the ancient convent of San Francisco (Las Palmas), both at the island of Gran Canaria (Figure 1 and Table 1). The production sites, which date from fourteenth to eighteenth centuries, have been involved in the manufacture of tin-lead glazed pottery since the Middle Ages, and some continue to produce majolica even today. Consequently, majolica production at a few of these places achieved high prestige due to their high quality and aesthetic value. The exportation of this pottery to the Americas, which became the case for the Seville and Talavera, eventually resulted in the establishment of autochthonous workshops, such as Puebla or Mexico City, both in Mexico (Castro, 1988; Gámez Martínez, 2003; LaBrecque et al., 2003; RodríguezAlegría et al., 2003).

Our goal is to obtain a more precise understanding of majolica pottery exports to the Americas through the study of cultural material found at the Canary Islands reception centers. Therefore, we require a reliable compositional databank based on pottery from the primary production sites of the Iberian Peninsula dating from the fourteenth to eighteenth centuries or, in other words, from the appearance of majolica until the 6 
introduction of porcelain production in Spain at the end of the eighteenth century. By identifying compositional reference groups for majolica production within the Iberian Peninsula, we aspire to identify the provenance of majolica that was exported from Spain to outside areas, such as the Canary Islands and the Americas. The identification of production centers for majolica recovered outside of Spain has important implications for understanding changing sociopolitical and economic relationships between Spain and the New World-relationships that may be at odds with historical documents of the era.

Despite the fact that many important archaometrical works concerning majolica pottery technology have been published, most of which are focused on lusterware (for instance, see Padeletti and Fermo, 2003; Polvorinos et al., 2006; Pradell et al., 2005; Roqué et al., 2007), archaeometric knowledge about tin-lead glazed pottery produced in the Iberian Peninsula is uneven. Consequently, there is an overall lack of chemically defined reference groups that characterize the primary production sites. Nonetheless, there have been a few studies that have focused on production sites in the Iberian Peninsula, such as Patern and Manises (Hughes, 1991, 1995; Hughes and Vince, 1986; Iñañez, 2007; Jornet et al., 1985; Molera et al., 1996; Molera et al., 2001), Barcelona, Lleida, Reus and Vilafranca del Penedès (Buxeda et al., 2001; Iñañez, 2007; Iñañez et al., 2007a; Iñañez and Buxeda, 2007; Iñañez et al., 2007c) and Talavera, Puente and Seville (Criado et al., 2002; Iñañez et al., in press-a). In addition, a few studies have examined the occurrence of Spanish majolica at overseas sites (e.g., the Americas), most of which refer to production in Seville (Jamieson and Hancock, 2004; Maggeti et al., 1984; Myers et al., 1992; Olin and Blackman, 1989; Olin et al., 1978; Olin and Myers, 1992; Vaz et al., 1997). However, when many of these provenance studies were conducted on 
majolica found in the Americas, there was a significant gap in the archaeological knowledge regarding the actual kiln sites at Seville. During the past several years, however, archaeological excavations have revealed a substantial number of such kiln sites—-sites that can be used to establish the reference groups (Iñañez et al., 2007b; Lorenzo Morilla et al., 1990; Mercado Hervás et al., 2001; Mesa Romero and Castañeda de la Paz, 2001).

\section{METHODS}

Table 1 lists the 208 majolica sherds that were analyzed in this study (for a more detailed description, pictures and drawings, see Iñañez 2007-available online at http://www.tesisenxarxa.net/TDX-0205107-115739/). All of the specimens were sampled from either extant museum collections or from contemporary archaeological excavations. Our sampling strategy was strictly focused on kiln-related materials to maximize the probability that the materials included in this study were a product of their respective workshops and production centers. In that sense, we focused on ceramics from archaeologically and historically-documented majolica kiln dumps; although in some cases we also sampled sherds from other types of archaeological deposits, such as the roof vaults at the old Hospital de la Santa Creu in Barcelona. The majority of the samples included in this study (97) were obtained from the Museu de la Ceràmica de Barcelona, a repository that has large reference collections for most of the primary majolica production sites in Spain, and Mr. J. A. Cerdà from the Associació Catalana de Ceràmica. We also obtained 15 sherds from the Museu Comarcal Salvador Vilaseca de Reus and 15 samples from the Museu de Vilafranca del Penedès. An additional 32 majolica fragments were selected from three different archaeological excavations within the city of Seville (Pureza, that is linked to the famous artist Niculoso Pisano's 
workshop, Valladares and Plaza de Armas). The samples were generously provided by the Museo Arqueológico de Sevilla, where the material from these excavations is curated. Finally, we obtained 15 specimens from the Servei Arqueològic de la ciutat de Lleida from three different archaeological sites (Obradors, St. Anastasi and Remolins) and 12 samples from Talavera de la Reina that were kindly provided by Mr. A. Sánchez Cabezudo. Colonial sherds from the Canary Islands were generously provided by the Parque Arqueológico Cueva Pintada de Gáldar (Gran Canaria) and the Museo Canario for the archaeological site of Ancient Convent of San Francisco (Las Palmas de Gran Canaria) (Figure 2).

In the present study, $10 \mathrm{~g}$ of each collected sample was powdered in a Spex Mixer (mod. 8000) tungsten carbide cell for $12 \mathrm{~min}$. Prior to grinding, glazes and exterior surfaces were mechanically removed by means of a tungsten carbide driller, using only the inner part of the ceramic for analysis in order to minimize contamination of glaze materials and soil. Powdered specimens were stored in polyethylene vials for transport to the laboratory.

Chemical analyses were conducted by instrumental neutron activation analysis (INAA) at the University of Missouri Research Reactor's Archaeometry Laboratory (MURR). Prior to weighing, the powdered pottery samples were oven-dried at $100^{\circ} \mathrm{C}$ for at least $24 \mathrm{~h}$. Approximately $150 \mathrm{mg}$ of sample were weighed in small polyvials used for short irradiations. At the same time, $200 \mathrm{mg}$ of each sample was weighed into high-purity quartz vials used for long irradiations. Along with the majolica samples, reference standards of SRM-1633a (coal fly) and SRM-688 (basalt rock) were prepared, as well 
as quality control samples of SRM-278 (obsidian rock) and Ohio Red Clay (for analytical conditions see Glascock et al., 2007) .

At MURR, INAA of pottery consists of two irradiations and a total of three gamma counts. Short irradiations involve a pair of samples being transported through a pneumatic tube system into the reactor core for a $5 \mathrm{~s}$ neutron irradiation using a thermal flux of $8 \times 10^{13} \mathrm{n} \mathrm{cm}^{-2} \mathrm{~s}^{-1}$. After 25 min of decay, the samples are counted for $720 \mathrm{~s}$ using a high-resolution germanium detector. This count yields data for nine short-life elements: Al, Ba, Ca, Dy, K, Mn, Na, Ti and V. For the long irradiation, bundles of 50 or 100 of the encapsulated quartz vials are irradiated for $24 \mathrm{~h}$ at a flux of $5 \times 10^{13} \mathrm{n} \mathrm{cm}^{-2}$ $\mathrm{s}^{-1}$. Following the long irradiation, samples decay for seven days, and then are counted for $1800 \mathrm{~s}$ (known as "middle count") on a high-resolution germanium detector coupled to an automatic sample changer. This middle count yields determination of seven medium half-life elements: As, La, Lu, Nd, Sm, U and Yb. After additional two-week decay, a second count for $9000 \mathrm{~s}$ is carried out on each sample. This final measurement allows quantification of 17 long-life elements: $\mathrm{Ce}, \mathrm{Co}, \mathrm{Cr}, \mathrm{Cs}, \mathrm{Eu}, \mathrm{Fe}, \mathrm{Hf}, \mathrm{Ni}, \mathrm{Rb}, \mathrm{Sb}$, Sc, Sr, Ta, Tb, Th, Zn and Zr (Glascock et al., 2007).

Statistical analysis of the data followed Aitchison's approach and Buxeda's observations on compositional data (Aitchison, 1986, 1996; Buxeda, 1999; Buxeda and Kilikoglou, 2003). The statistical procedure consists of the use of ratios of base-10 logarithms obtained by dividing all the components, in this case the elements, by the element that introduces the lowest chemical variability to the entire set of specimens. Using logarithms compensates for differences in magnitudes between major elements, such as $\mathrm{Al}$ and $\mathrm{Fe}$, and trace elements, such as the lanthanide and rare earth elements 10 
(e.g. La, Ce, Sm, etc.). By dividing all components by the component that exhibits the lowest variability, one also overcomes relative magnitudes problems of a given subcomposition. For instance, usually $\mathrm{s}_{\mathrm{i}} \neq \mathrm{x}_{\mathrm{i}}$ and it may result in spurious correlations. However, working with logratio transformation we deal with the same relative magnitudes for each specimen, given that $\mathrm{s}_{\mathrm{i}} / \mathrm{s}_{\mathrm{j}}=\mathrm{x}_{\mathrm{i}} / \mathrm{x}_{\mathrm{j}}$ (Aitchison et al., 2000). Finally, logratio transformations can highlight possible perturbations in the chemical data as a result of diagenesis, contamination, or other alteration processes (Buxeda, 1999).

The data were examined using an array of multivariate statistical procedures. The application of multivariate statistical techniques to INAA data facilitates identification of compositional groups. Therefore, the similarity between specimens, and subsequently to their hypothetical provenance according to the provenance postulate (Weigand et al., 1977), was examined using scatter plots, whereas Stepwise Discriminant Analysis (DA) was performed to assess the archaeological classifications and the chemical groups proposed by scatter plots. In addition, Mahalanobis distance was used to describe the statistical probability, when group sizes permitted, the separation between defined groups and those individuals that remained unclassified. Mahalanobis distance takes into account variances and covariances in the multivariate group and is analogous to expressing the distance from a univariate mean in standard deviation units (Baxter, 1999). In that sense, Mahalanobis distance can also be converted into probabilities of group membership for each individual (Glascock, 1992; Neff et al., 2003).

Although sample preparation was conducted under great care to minimize the analytical error, the potential for contamination exists nonetheless. In that sense, a conservative approach to data interpretation is warranted. For example, we considered that the 11 
element cobalt had to be removed from consideration during the statistical treatment because the tungsten carbide cell grinder exhibits traces of $\mathrm{Co}$ in its chemical composition (cobalt is a known binder in tungsten alloys). Additionally, $\mathrm{Ni}$ concentrations were below detection limits for many of the samples and subsequently had to be removed from consideration.

Conversely, since most of the individuals have been also analyzed by X-Ray Diffraction analyses (the analytical routines have been described elsewhere: Iñañez 2007), it has been possible to observe that a relevant number of the analyzed majolica sherds exhibited a double process of alteration and contamination (Figure 3), also documented in previous studies (Iñañez, 2007; Iñañez and Buxeda, 2007; Iñañez et al., in press-b). This process reports the leaching of potassium and, sometimes, rubidium, from the matrix, with a subsequent enrichment of sodium because of analcime crystallization (Buxeda et al., 2002; Iñañez, 2007, and references therein; Schwedt et al., 2006). Therefore, these alteration and contamination processes affect those components in the matrix composition, without any possibility of calculating a satisfactory correction. As a result, $\mathrm{Na}, \mathrm{K}$, and $\mathrm{Rb}$ were also removed from consideration during the statistical analysis.

\section{RESULTS AND DISCUSSION}

The variability of each chemical component was first taken into account in this study and assessed by calculating the variation matrix using the S-plus program (MathSoft, 1999), which provides information about those components that introduce higher variability to the data set (Table 2). Consequently, the elements $\mathrm{As}$ and $\mathrm{Sb}$ were 
removed due to their high variability $\left(\mathrm{vt} / \tau_{\mathrm{i}}<0.25\right)$, which is presumably provided by possible contamination processes during burial, such is the case of As. Besides, $\mathrm{Sb}$ is known as a contaminant of $\mathrm{Sn}$, an important component of majolica glazes, and many majolica exhibit yellow decoration that is essentially made of $\mathrm{Sb}$. Therefore, $\mathrm{Sb}$ is likely diffused into the clay matrix. As mentioned above, $\mathrm{Rb}, \mathrm{K}$ and $\mathrm{Na}$ were removed because they are involved in the previously cited alteration, consequently exhibiting high chemical variability too $\left(\mathrm{vt} / \tau_{\mathrm{i}}<0.45\right)$. In addition, $\mathrm{U}$ and $\mathrm{Tb}$ were also removed from consideration due to their poor analytical precision. Although $\mathrm{Ba}$ also exhibits a high variation, this is mainly reported by few individuals (MJ0104, MJ0141, MJ0341 and DIA317) with three to seven times the normal $\mathrm{Ba}$ amounts of their respective groups, probably as a contamination. Therefore, Ba can be kept as a variable in the statistical treatment once taken this latter problem into account. Following the exclusion of these elements, a base-10 logarithm ratio transformation was applied to the following subcomposition: La, Lu, Nd, Sm, Yb, Ce, Cr, Cs, Fe, Hf, Sc, Sr, Ta, Th, Zn, Zr, Al, Ba, $\mathrm{Ca}, \mathrm{Dy}, \mathrm{Mn}$, Ti and V, using Eu as divisor because it introduces the lowest variability to the data set $\left(\mathrm{vt} / \tau_{\mathrm{i}}=0.93\right)$.

The results are summarized in the Figures 4 and 5, and Table 3. An examination of scatter plots facilitated the identification of 13 discrete chemical reference groups from the primary production centers of the Iberian Peninsula: Barcelona Drassanes (BCNDR), Barcelona Hospital de la Santa Creu (BCN-SC), Reus, Muel 1 and 2, Villafeliche, Manises, Puente del Arzobispo, Vilafranca del Penedès (VdP), Lleida Obradors/Sant Anastasi (OB/SA), Lleida Remolins (REM), Talavera and Sevilla. In addition, we identified two different paste reference groups found within the sherds sampled in the Canary sites that we attribute to unidentified Ligurian and Portuguese productions. 13 
Despite the low number of specimens that comprise the Ligurian $(n=4)$ and the Portuguese $(n=2)$ groups, there is archaeological and chemical evidence that corroborate their existence. Data for the Ligurian group is not shown in Figure 3 given that the significantly higher chromium and nickel concentrations distort the graphical representation of the other groups. These relatively high chromium and nickel concentrations suggest an ophiolitic origin for these sherds, such as the Ligurian and northern Italy regions (Maggetti, 2005), reinforcing their typological/stylistic classification as either Ligurian or Italian productions. Moreover, and possibly a consequence to the high standardization and chemical similarity of the materials, some of the groups that can be separated show some overlap, resulting in two large clusters of samples. On the contrary, clear group separation among the samples that comprise the Reus, VdP, REM and Portuguese groups is achieved in Figure 3. Consequently, and for a better visual group separation purposes, separation of the remaining groups are shown in separate plots (Figures 4 and 5). Figure 4 depicts the spatial distribution of BCN-DR, BCN-PI, Teruel 1, Teruel 2 and Paterna groups using $\mathrm{Ca} / \mathrm{Eu}, \mathrm{Mn} / \mathrm{Eu}$ and $\mathrm{Sc} / \mathrm{Eu}$ base-10 logarithms values as variables. Chemical differentiation among the $\mathrm{BCN}-\mathrm{SC}$, Muel 2, Villafeliche, Manises, Puente del Arzobispo, OB/SA, Talavera and Sevilla is graphically represented in Figure 5, a bivariate plot of $\mathrm{Fe} / \mathrm{Eu}$ and $\mathrm{Th} / \mathrm{Eu}$ base-10 logarithms ratios. Graphic separation between Talavera and Puente groups presents some problems due to their chemical similarity. These cities are geographically very close to each other and have had a very similar majolica production history during the past four centuries. There are many problems that hinder the discrimination between these production centers, especially on the basis of their decorative styles and typologies. Additionally, tableware production styles from Puente have traditionally been considered to be an imitation of the Talavera's (Sánchez-Pacheco, 1997). 14 
Therefore, and related to their close proximity, chemical data generated for several sherds analyzed from both sites exhibit a similar composition (Iñañez et al., in press-a) resulting in an overlapping group structure that requires additional study. It must be underscored that the Muel 1 group has not been shown in the latter plot given that the chemical composition for this group, although clearly a different group chemically, causes a distortion in the overall group representation shown in Figure 5.

Through the study of the different spatial representation graphics shown in here (Figures 3-5), we argue that most of the pottery sampled from the Canary Islands exhibit high resemblance with the Sevilla reference group. This conclusion is in agreement with the historical and archaeological data. In addition, 2 lusterware specimens, one from the Cueva Pintada (MJ0236) and one from the Ancient Convent of San Francisco (MJ0285), are an excellent match with the Manises reference group. In addition, a blue on white sherd (MJ0293) also presents a high chemical similarity with the Catalan group of BCN-SC. Conversely, there are a few samples that do not correspond with any reference group (MJ0262, MJ0269, MJ0284, and MJ0294). According to the archaeological data, MJ0284 is a sgraffito ware, which is technologically different and also exhibits higher $\mathrm{Ni}$ and $\mathrm{Cr}$ amounts, although not as high as the Ligurian majolica. Furthermore, MJ0269 has been archaeologically classified as Delftware, a plausible interpretation given that chemical composition of this sample does not seem to match any reference group from the Iberian Peninsula or Italy. On the other hand, MJ0289 has been also classified by typology and decoration also as Delftware, while its chemical composition indicates a Sevillan origin. Finally, as discussed above, there are six samples that we attribute to the Liguria region and Portugal. 
In order to achieve a better discrimination among the groups previously identified by scatter plots, a stepwise discriminant analysis was performed on the chemical data set using all of the analyzed samples. The most suitable components for running the discriminant analysis were the same as those used for the scatter plots following the logratio transformation. Stepwise discriminant analyses were performed, using the Statgraphics Plus program, on the subcomposition $\mathrm{La}, \mathrm{Lu}, \mathrm{Nd}, \mathrm{Sm}, \mathrm{Yb}, \mathrm{Ce}, \mathrm{Cr}, \mathrm{Cs}, \mathrm{Fe}$, Hf, Sc, Sr, Ta, Th, Zn, Zr, Al, Ba, Ca, Dy, Mn, Ti and V, using Eu as the divisor in the logratio transformation (Table 2). As discussed above, elements presumed to be problematic because of alteration or contamination processes, such as $\mathrm{Co}, \mathrm{Na}, \mathrm{Rb}$ or $\mathrm{K}$, and those components also dismissed from the scatter plots because of their high variability or analytical problems (e.g., As, $\mathrm{U}, \mathrm{Ni}, \mathrm{Tb}$, and $\mathrm{Sb}$ ), were not considered in the stepwise discriminant analysis.

Stepwise discriminant analysis (DA) provides a powerful tool to assess the groups identified by scatter plots. Using a stepwise selection algorithm, it was determined that 18 variables (the logratio transformed components: $\mathrm{Cr}$, Th, $\mathrm{Cs}, \mathrm{Sc}, \mathrm{Ca}, \mathrm{Ta}, \mathrm{Sm}, \mathrm{Hf}, \mathrm{Sr}$, $\mathrm{Fe}, \mathrm{Al}, \mathrm{La}, \mathrm{Mn}, \mathrm{Ce}, \mathrm{Zn}, \mathrm{V}, \mathrm{Ti}$ and $\mathrm{Lu}$ ) are significant predictors of majolica groups. The 16 discriminating functions with P-values less than 0.05 are statistically significant at the $95 \%$ confidence level. The evaluation of all the sherds classified regarding to the previous plots has shown a very high successful score: $98.13 \%$, in which 263 out of 268 sherds match their suggested group according to the scatter plots and the archaeological information. As a result, DA has operated in a successful manner for those sherds from different archaeological contexts, but with a similar chemical composition that results in a single chemical group in the spatial distribution, such as the cases of Talavera and 
Puente. Thus, unique groups for the producing towns of Talavera and Puente were identified according to their hidden chemical differences, although one specimen from Puente and two from Talavera still indicate an ambiguous origin. Regarding the Canary specimens, 11 out of 22 of the individuals from are assigned to a Sevillan origin by DA, as expected by the scatter plots and the historical documentation. The three lusterware majolicas are attributed to Sevilla (MJ0286) and to Manises (MJ0236 and MJ0285), whereas the blue on white specimen (MJ0293) clearly is attributed to the BCN-SC group, supporting the previous classification made by scatter plots. Additionally, the proposed Ligurian and Portuguese groups are supported by DA, forming their own respective groups with no attribution to any other group. Nevertheless, individual MJ0269, archaeologically classified as Delft series, is classified by similarity as a Sevillan product, as MJ0284 and MJ0294 do so with OB/SA.

In order to assess the statistical strength of the groups suggested by the scatter plots and confirmed by the stepwise DA, a probabilistic group assignment based on Mahalanobis distance calculations was performed. However, the limited number of samples for some of the reference groups precluded the possibility of employing all the chemical variables measured by INAA or the 18 most discriminating transformed variables for this dataset because most of the suggested groups are comprised of about fifteen specimens. Thus, another scale reducing statistical technique is needed, such as Principal Components analysis (PCA). PCA was performed in the same way as the stepwise DA and the scatter plots: that is employing the subcomposition $\mathrm{La}, \mathrm{Lu}, \mathrm{Nd}, \mathrm{Sm}, \mathrm{Yb}, \mathrm{Ce}, \mathrm{Cr}, \mathrm{Cs}, \mathrm{Fe}$, Hf, Sc, Sr, Ta, Th, Zn, Zr, Al, Ba, Ca, Dy, Mn, Ti and V, using Eu as divisor in the logratio transformation (Table 2). Likewise, $\mathrm{As}, \mathrm{K}, \mathrm{Na}, \mathrm{Rb} \mathrm{U}, \mathrm{Tb}$ and $\mathrm{Sb}$, were not included for reasons discussed above. The PCA indicated that $95 \%$ of the cumulative 17 
variance was accounted for in the 9 first principal components, resulting in a good estimation of the overall composition of the majolica sherds. Given that the majolica production center groups identified by scatter plots and DA are usually smaller in number than 18 and normally larger than 11 , it was possible to calculate MD probabilities using the first nine principal components to assess the membership probabilities for Canary samples assigned to each group and those that form their own groups, such as the Ligurian and Portuguese sherds. It must be highlighted that the two groups that do not agree with the number restriction rule were the chemical groups proposed for REM and BCN-SC, having both less than 11 sherds each one.

The MD calculations (Table 4), once converted into membership probabilities, clearly confirm that the groups previously identified by scatter plots and DA are statistically robust. Consequently, most of the sherds are assigned with a higher probability of $5 \%$, a theoretical limit of membership probability, to their respective chemical groups in the same way that they did by scatter plots and DA. In the same sense, the provenance of the specimens that showed a discrepancy amongst the classification by scatter plots of by DA is now in agreement with MD probabilities. Therefore, eight of the individuals from the Canary sites can be assigned to the Sevilla reference group, including MJ0262, which exhibited certain differences in the scatter plots. In the same way, MJ0236 and MJ0285 exhibit high membership probabilities of belonging to Manises group, as suggested by scatter plots and DA.

As is common with MD probabilities, some samples could not be assigned to any group. None of the four individuals archaeologically classified as Ligurian and confirmed to be distinct by scatter plots and DA show any probability of belonging to 18 
any reference group from the Iberian Peninsula. The low MD probabilities and the high $\mathrm{Ni}$ and $\mathrm{Cr}$ concentration of these sherds reinforces the hypothesis that these sherds were produced in the Ligurian region or northern Italy. In addition, the two samples classified as Portuguese by archaeologists, and which based on scatter plots and DA also could not be linked to any reference group from Spain, have low probabilities of membership in any of the references groups. Sample MJ0284, which is typologically classified as a sgraffito ware, exhibits a very low probability of membership in any of the reference groups, suggesting that this sample should be classified as unassigned. Moreover, and as a result of the number restrictions for MD calculations, MJ0293 could not be compared with the of BCN-SC group due to the low number of samples assigned to this group. However, although it shows a high membership probability with the Manises group, a BCN-SC provenance can be suggested in agreement with the DA attribution and scatter analysis (see Figures 4, 5 and 6). Future studies, which will increase the number of samples for the reference group allowing the MD calculations, might corroborate the final provenance suggested for this sample. Samples MJ0287 and MJ0288, which were assigned to Sevilla by scatter plots and DA, were not be assigned to any of the reference groups due to the low MD membership probabilities. Therefore, we classified these as unassigned. Finally, sample MJ0294, the only black and green majolica, cannot be assigned to any reference group by scatter plots or MD. Therefore, it must remain as unassigned also.

Results confirm the existence of differences among the two reception sites from Gran Canaria Island in terms of pottery provenance. Thus, the Cueva Pintada pottery only shows two different provenances, Seville and Manises. Whereas, the Ancient Convent of San Francisco in Las Palmas exhibits a wider provenance for its pottery, revealing 19 
the existence of at least five different productions: Seville, Liguria, Portugal, Barcelona and Delft. This different number of provenances for both sites may explain us about the different roles and chronologies played by both sites. While the Cueva Pintada samples are dated back to the late $15^{\text {th }}$ and early $16^{\text {th }}$ centuries, the samples from the Ancient Convent of San Francisco are dated to the $16^{\text {th }}$ and $17^{\text {th }}$ centuries. Moreover, the site of Cueva Pintada was a secondary place in terms of importance since the capital of the island was settled in Las Palmas. Whereas, the Ancient Convent of San Francisco became an important religious community in the Capital and the entire island during the $16^{\text {th }}$ and $17^{\text {th }}$ centuries, playing a relevant social role in the Canary society.

In terms of types of pottery, the results show that lusterware recovered at Gran Canaria had origins in Sevilla and Manises. This is reasonable, given that the most important production from Manises is lusterware. And, it was the most luxurious ceramic ware until the beginning of the $17^{\text {th }}$ century (Soler, 1997).

Surprisingly, the blue-on-white MJ0293 sample can be attributed, according to the scatter plots and 'DA analyses, to the Catalan $\mathrm{BCN}-\mathrm{SC}$ group-a group exclusively comprised of lusterware pottery so far. Therefore, the results from Gran Canaria are not only the first identification of BCN-SC ceramics outside of Barcelona, but also this sample provides compelling evidence for the first example of a non-lusterware ceramic that has been identified as a product of $\mathrm{BCN}-\mathrm{SC}$ group.

The Sevillian production center is by far the most represented group in Gran Canaria. Moreover, it also is very heterogeneous in terms of types of pottery documentedlusterware $(n=1)$, Sevillan white $(n=4)$, Columbia Simple $(n=2)$ and Isabela 20 
polychrome $(\mathrm{n}=1)$. In addition, one green tile also has a Sevillan origin (MJ0253). A special case is raised by one sample, MJ0289, archaeologically classified as Delft. In fact, as it has been already addressed above, sample MJ0269 was archaeologically classified as a Delft product. The fact that chemically this sample does not cluster to any defined group, and in the absence of other data, would seem to support an actual Dutch origin. On the contrary, sample MJ0289, which chemically corresponds to Seville reference group, might be a Delft imitation. The existence of such imitations has been hypothesized on historical and archaeological grounds (Pleguezuelo and Sánchez Cortegana, 1997) and has now confirmed archaeometrically.

The blue-on-white type is present, as stated above, at the BCN-SC group and also in the Portuguese (2 samples) and Ligurian groups (4 samples). Hence, this type of majolica exhibits the highest dispersion concerning its origin among the pottery from Gran Canaria.

Finally, the only sgrafitto ware could not be assigned to any of the compositional groups. However, it is noteworthy that its Fe content is the highest for this shard among the studied materials. This feature, together with a relatively medium $\mathrm{Ca}$ content, provides a characteristic red color for the clay body. This color, which would be undesirable in majolica, is a desired effect for sgraffito pottery (Lazzarini et al., 1980).

\section{CONCLUSION}

The origin of the American trade monopoly can be attributed to the establishment of the Casa de la Contratación in Seville in 1503. This organization directly controlled all 21 
trade of goods that were shipped to the Americas from the Castilian Kingdom. Consequently, between $15^{\text {th }}$ to $18^{\text {th }}$ centuries Sevillan potters produced the majority of majolica exported to the Americas (Sánchez Cortegana, 1994). Therefore, Sevillan pottery has a high occurrence in the archaeological records of the Canary Islands and in sites in the Americas. The present study confirms that most of the ceramics from the sites of La Cueva Pintada and the San Francisco's convent are in agreement with a Sevillan provenance. Nevertheless, Seville was not the only production center that was exporting pottery shipped to the Americas.

The historical sources, especially numerous notarial and commercial manuscripts generated by the Casa de la Contratación and preserved in the Archivo de Indias, tell us about the existence of a strong control in this trade network. Furthermore, the repetitive pleas by the Canary Island merchants to increase their market share with America also point to such a situation. The occurrence of pottery of different origins might then be explained by several possibilities that do not exclude each other. On the one hand, despite the very tight control of the Castilian monopoly, a vigorous smuggling activity could be plausible based on the archaeological and archaeometric studies. It has to be highlighted that, from the Iberian Peninsula (except Portugal and its colonies), only Castilian merchants had license to trade with America, therefore other entities could not legally provide pottery from other sources. As a result of this monopoly, territories belonging to the Aragon Kingdom, such as Barcelona or Valencia, would not be allowed to trade with America until 1778. On the other hand, objects of non-Sevillan origin could have been included in cargos by Castilian merchants themselves, when the potters from Seville were unable to provide a comparable product (Pleguezuelo, 2003; Pleguezuelo and Sánchez Cortegana, 1997). Surprisingly, no majolica ware from 22 
Talavera de la Reina has been found within the analyzed samples, despite the relevant role that this production center played during the $16^{\text {th }}$ and $17^{\text {th }}$ centuries in Spain.

The present study suggests the arrival of ceramics and possibly other goods, from different places around the Mediterranean, such as Italy, Manises or Barcelona; Portugal; and possibly Holland. The extent of the participation of all these different productions centers, and their impact and the variety of products involved in this process remains to be assessed. However, this study shows that the trade network, the most important one at that time, is far more complex than previously assumed. The exact mechanisms by which the different pottery enters these flows, whether it is licit or illicit, might not be easily understood, but the work must be extended in order to obtain a more comprehensive picture. Canary Islands' role in this network becomes, then, a central subject of research for achieving a deeper understanding of the colonial artifacts found at the Americas.

\section{ACKNOWLEDGMENTS}

This work forms part of the project "Identification, Recovery and Improvement of ancient Mediterranean ceramic manufacturing technologies for the reproduction of ceramic artifacts of archaeological value (CERAMED)", from the Research Directorate General, European Commission, European Community (ICA-3-CT-2002-10018). Javier G. Iñañez is also indebted to the Smithsonian Institution postdoctoral fellowship program for its support. Authors are also indebted to the Museu de la Ceràmica de Barcelona, Museo Arqueológico de Sevilla, Museo Canario (Las Palmas de Gran Canaria) and Parque Arqueológico de la Cueva Pintada (Gáldar, Gran Canaria), Mr. 
Sánchez Cabezudo and Josep A. Cerdà from the Associació Catalana de Terrissa i Ceràmica Decorada for their collaboration providing the samples. Special thanks are extended to Nicole Little for assistance with laboratory work at MURR and to Dan Cole for assistance with the illustrations. The laboratory work at MURR was supported in part by National Science Foundation grant no. 0504015. 


\section{REFERENCES}

Aitchison, J., 1986, The statistical analysis of compositional data: Monographs on Statistics and Applied Probability: London - New York, Chapman and Hall.

Aitchison, J., 1996, On criteria for mesures of compositional difference, Mathematical Geology, 24(4), 365 - 379.

Aitchison, J., C. Barceló, J. A. Martín, and V. Pawlowsky-Glahn, 2000, Logratio analysis and compositional distance, Mathematical Geology, 32(3), 271 - 275.

Baxter, 1999, Detecting multivariate outliers in artifact compositional data, Archaeometry, 41, 321-338.

Buxeda, J., 1999, Alteration and Contamination of Archaeological Ceramics: The Perturbation Problem, Journal of Archaeological Science, 26(3), 295-313.

Buxeda, J., and V. Kilikoglou, 2003, Total variation as a measure of variability in chemical data sets, in Patterns and Process, a Festschrift in honor of Dr. Edward V.Sayre, 185 - 198, L. Van Zelst, ed., Smithsonian Center for Materials Research and Education, Suitland, Maryland.

Buxeda, J., M. Madrid Fernández, and J. M. Gurt i Esparraguera, 2001, Provinença i tecnologia de les ceràmiques de pisa i d'obra de Manises del dipòsit de la Plaça Gran de Mataró, in La ceràmica catalana del segle XVII trobada a la plaça Gran (Mataró), 155 - 170, Associació Catalana de Ceràmica Decorada i Terrissa, Barcelona.

Buxeda, J., H. Mommsen, and A. Tsolakidou, 2002, Alterations of Na, K and Rb concentrations in Mycenaean pottery and a proposed explanation using X-ray diffraction, Archaeometry, 44(2), 187-198.

Castro, O., 1988, Algunas noticias acerca de la cerámica loza fina de puebla.: Lecturas Históricas de Puebla, v. 18: Puebla (México), Gobierno del Estado: Secretaría de Cultura, $39 \mathrm{p}$.

Criado, E., P. Recio, J. C. Fariñas, and D. Portela, 2002, Preliminary archaeometric study on ancient pottery of Puente del Arzobispo (Toledo, Spain), Key Engineering Materials, 206-213, 917-922. 
Gámez Martínez, A. P., 2003, The forgotten potters of Mexico City, in Cerámica y Cultura. The Story of Spanish Mexican Mayólica, 227 - 243, R. Farwell, D. Pierce, and A. Pleguezuelo, eds., University of New Mexico Press, Albuquerque.

Glascock, M. D., 1992, Characterization of archaeological ceramic at MURR by Neutron Activation analysis and Multivariate statistic, in Chemical Characterization of Ceramic Pastes in Archaeology, 11 - 25, H. Neff, ed., Monographs in World Archaeology, Prehistory Press, Madison, Wisconsin.

Glascock, M. D., R. J. Speakman, and H. Neff, 2007, Archaeometry at the University of Missouri Research Reactor and the provenance of obsidian artefacts in North America, Archaeometry, 49(2), 343-357.

Hughes, M. J., 1991, Provenance studies of Spanish medieval tin-glazed pottery by neutron activation analysis, in Archaeological Sciences 1989, 54 - 68, P. Budd, B. Chapman, C. Jackson, R. C. Janaway, and B. Ottaway, eds., Oxbow, Oxford.

Hughes, M. J., 1995, Application of scientific analytical methods to Spanish medieval ceramics, in Spanish Medieval Ceramis in Spain and the British Isles, 359 - 366, C. M. Gerrard, A. Gutiérrez, and A. G. Vince, eds., BAR International Series, Oxford.

Hughes, M. J., and A. G. Vince, 1986, Neutron activation analysis and petrology of Hispano-Moresque pottery, in Proceedings of the 24th International Archaeometry symposium, 353 - 367, J. S. Olin, and M. J. Blackman, eds., Smithsonian Institution Press, Washington DC.

Iñañez, J. G., 2007, Caracterització arqueomètrica de la ceràmica vidrada decorada de la Baixa Edat Mitjana al Renaixement dels principals centres productors de la Península Ibèrica: Tesis Doctorals en Xarxa, v. 0205107-115739: Barcelona, Universitat de Barcelona.

Iñañez, J. G., J. Buxeda i Garrigós, M. D. Glascock, and R. J. Speakman, in press-a, Archaeometric characterization of Renaissance tin lead glazed pottery from Talavera de la Reina, Puente del Arzobispo and Seville (Spain): 36th International Symposium on Archaeometry (ISA 2006).

Iñañez, J. G., J. Buxeda i Garrigós, M. Madrid Fernández, J. M. Gurt i Esparraguera, and J. A. Cerdà i Mellado, 2007a, Archaeometric characterization of Middle Age and Renaissance tin lead glazed pottery from Barcelona, in Archaeometric and Archaeological Approaches to Ceramics, 175-180, S. Y. Waksman, ed., BAR International Series, Archaeopress, Oxford. 
Iñañez, J. G., J. Buxeda i Garrigós, R. J. Speakman, M. D. Glascock, and E. Sosa Suárez, 2007b, Characterization of $15^{\text {th }}-16^{\text {th }}$ Century majolica pottery found on the Canary Islands, in Archaeological Chemistry: Analytical Techniques and Archaeological Interpretation, 376-398, M. D. Glascock, R. J. Speakman, and R. S. Popelka-Filcoff, eds., ACS Symposium Series, American Chemical Society, Washington D.C.

Iñañez, J. G., and J. Buxeda, 2007, Pisa arcaica i ceràmica vidrada del segle XIII a Barcelona. Un estudi arqueomètric, Quarhis - Quaderns d'Arqueologia i Història de la Ciutat de Barcelona, 3, 160-179.

Iñañez, J. G., A. Schwedt, M. Madrid i Fernández, J. Buxeda i Garrigós, and J. M. Gurt i Esparraguera, 2007c, Caracterización arqueométrica de los principales centros productores catalanes de cerámica mayólica de los siglos XVI y XVII, in Avances en Arqueometría 2005. Actas del VI Congreso Ibérico de Arqueometría, 97-107, J. Molera, J. Farjas, P. Roura, and T. Pradell, eds., Universitat de Girona, Girona.

Iñañez, J. G., A. Schwedt, M. Madrid i Fernández, J. Buxeda i Garrigós, and J. M. Gurt i Esparraguera, in press-b, Caracterización arqueométrica de los principales centros productores catalanes de cerámica mayólica de los siglos XVI y XVII, in Actas del $6^{\circ}$ Congreso Ibérico de Arqueometría J. Molera, ed., Girona.

Jamieson, R. W., and R. G. V. Hancock, 2004, Neutron activation analysis of colonial ceramics from Southern Highland Ecuador, Archaeometry, 46(4), 569-583.

Jornet, A., M. J. Blackman, and J. S. Olin, 1985, 13th to 18th century ceramics from the Paterna-Manises area (Spain), in Ancient technology to modern sciences, 235 - 255, W. D. Kingery, ed., I, The American Ceramic Society, Columbus.

Kingery, W. D., and W. D. Aronson, 1990, On the technology of Renaissance Maiolica glazes, Faenza, 5, 226 - 234.

LaBrecque, J. J., J. E. Vaz, and J. M. Cruxent, 2003, Further investigation of majolica ceramics assigned to the Puebla (Mexico) provenance by radioisotope induced $\mathrm{x}$-ray fluorescence, X-Ray Spectrometry, 32(1), 25-28.

Lazzarini, L., S. Calogero, N. Burriesci, and M. Petrera, 1980, Chemical, mineralogical and Mössbauer studies of Venetian and Paduan Renaissance sgraffito ceramics, Archaeometry, 22(1), 57 - 68.

Lorenzo Morilla, J., M. Vera Reina, and J. Escudero Cuesta, 1990, Intervención arqueológica en c/ Pureza, num. 44 de Sevilla, in Anuario Arqueológico de Andalucía 
1987. Actividades de Urgencia, Informes y Memorias, 574 - 580, Consejería de Cultura de la Junta de Andalucía, Sevilla.

Maggeti, M., Westley, and J. S. Olin, 1984, Provenance and technical studies of Mexican Majolica using elemental and phase analysis, American Chemical Society, 151 $-191$.

Maggetti, M., 2005, The Alps; a barrier or a passage for ceramic trade?, Archaeometry, 47(2), 389-401.

MathSoft, 1999, S-PLUS 2000. User's Guide: Seattle, Data Analysis Products Division, MathSoft.

Mercado Hervás, L., M. J. Paz Jorva, and J. C. Mejías García, 2001, Seguimiento arqueológico de la antigua estación de ferrocarril conocida como "Plaza de Armas", Sevilla, in Anuario Arqueológico de Andalucía 1998. Actividades de Urgencia, Informes y Memorias, 715-721, Consejería de Cultura de la Junta de Andalucía, Sevilla.

Mesa Romero, M., and M. Castañeda de la Paz, 2001, Intervención arqueológica de urgencia en los solares de calle Betis 36 y Pureza 81 (Triana, Sevilla), in Anuario Arqueológico de Andalucía 1997, Consejería de Cultura de la Junta de Andalucía, Sevilla.

Molera, J., M. García, T. Pradel, and M. Vendrell-Saz, 1996, Hispano-moresque pottery production of the fourteenth-century workshop of Testar del Molí (Paterna, Spain), Archaeometry, 38(1), 67 - 80.

Molera, J., T. Pradell Cara, M. Mesquida, and M. Vendrell-Saz, 2001, Características técnicas y procesos de producción de las cerámicas del s. XIII en Paterna, in Las ollerías de Paterna. Tecnología y producción del s. XII y s. XIII, 235 - 261, M. Mesquida, J. E. López Peris, S. Prades, and R. Smolka, eds., Ayuntamiento de Paterna, Paterna.

Molera, J., T. Pradell, N. Salvado, and M. Vendrell-Saz, 1999, Evidence of tin oxide recrystallization in opacified lead glazes, Journal of the American Ceramic Society, 82(10), 2871-2875.

Myers, J. E., F. Amores, J. Olin, and A. Pleguezuelo, 1992, Compositional identification of Seville Majolica at Overseas sites, Historical Archaeology, 26(1), 131 147. 
Neff, H., J. W. Cogswell, and L. M. J. Ross, 2003, Supplementing bulk chemistry in archaeological ceramic provenance investigations, in Patterns and Process: a Festschrift in honor of Dr. Edward V.Sayre, 201 - 226, L. Van Zelst, ed., Smithsonian Center for Materials Research and Education, Suitland, Maryland.

Olin, J. S., and M. J. Blackman, 1989, Compositional classification of Mexican majolica ceramics of the Spanish Colonial period, in Archaeological Chemistry IV, 87 112, R. O. Allen, ed., Advances in chemistry series, 220, American Chemical Society, Washington DC.

Olin, J. S., G. Harbottle, and E. V. Sayre, 1978, Elemental compositions of Spanish and Spanish-Colonial Majolica ceramics in the identification of provenience, in Archaeological Chemistry II 200 - 229, G. F. Carter, ed., Advances in Chemistry Series, American Chemical Society, Washington DC.

Olin, J. S., and J. E. Myers, 1992, Old and New World Spanish Majolica Technology, Materials Research Society Bulletin, 17(1), 32 - 38.

Onrubia, J., C. Rodríguez Santana, and J. I. Sáenz Sagasti, 2004, El proyecto Cueva Pintada y la arqueología prehispánica de Gáldar (Gran Canaria). Balance y perspectivas de dos décadas de investigaciones, Anuario de

Estudios Atlánticos, 50, 705-730.

Padeletti, G., and P. Fermo, 2003, How the masters in Umbria, Italy, generated and used nanoparticles in art fabrication during the Renaissance period, Applied Physics A: Materials Science \& Processing, 76(4), 515-525.

Pleguezuelo, A., 2003, Centers of traditional Spanish mayolica, in Cerámica y Cultura. The Story of Spanish Mexican Mayólica, 24 - 47, R. Farwell, D. Pierce, and A. Pleguezuelo, eds., University of New Mexico Press, Albuquerque.

Pleguezuelo, A., and J. M. Sánchez Cortegana, 1997, La exportación hacia América de cerámica europeas (1492-1650), in Transferències $i$ comerç de ceràmica a l'Europa Mediterrània: Actes de les XV Jornades d'Estudis Històrics Locals, 333 - 363, Institut d'Estudis Baleàrics, Palma de Mallorca.

Polvorinos, A., J. Castaing, and M. Aucouturier, 2006, Metallic nano-particles in lustre glazed ceramics from the 15th century in Seville studied by PIXE and RBS, Nuclear Instruments and Methods in Physics Research Section B: Beam Interactions with Materials and Atoms, 249(1-2), 596-600. 
Pradell, T., J. Molera, J. Roque, M. Vendrell-Saz, A. D. Smith, E. Pantos, and D. Crespo, 2005, Ionic-Exchange Mechanism in the Formation of Medieval Luster Decorations, Journal of the American Ceramic Society, 88(5), 1281-1289.

Rodríguez-Alegría, E., H. Neff, and M. D. Glascock, 2003, Indigenous ware or Spanish import? The case of indígena ware and approaches to power in Colonial Mexico Latin American Antiquity, 14(1), 67 - 81.

Roqué, J., J. Molera, J. Pérez-Arantegui, C. Calabuig, J. Portillo, and M. Vendrell-Saz, 2007, Lustre colour and shine from the Olleries Xiques workshop in Paterna (Spain), $13^{\text {th }}$ century AD: nanostructure, chemical composition and annealing conditions, Archaeometry, 49(3), 511-528.

Sánchez-Pacheco, T., 1997, Cerámica de Talavera de la Reina y Puente del Arzobispo, in Cerámica española, 305 - 342, T. Sánchez-Pacheco, ed., Summa Artis, Espasa Calpe, S.A., Madrid.

Sánchez Cortegana, J. M., 1994, El Oficio de ollero en Sevilla en el siglo XVI: Arte Hispalense, v. 65: Sevilla, Diputación Provincial de Sevilla.

Schwedt, A., H. Mommsen, N. Zacharias, and J. Buxeda i Garrigós, 2006, Analcime crystallization and compositional profiles - comparing approaches to detect postdepositional alterations in archaeological pottery, Archaeometry, 48(2), 237-251.

Soler, M. P., 1997, Cerámica Valenciana, in Cerámica española, 135 - 178, T. SánchezPacheco, ed., Summa Artis, Espasa Calpe, S.A., Madrid.

Sosa Suárez, E., 2002, Las cerámicas del antiguo convento de San Francisco de Las Palmas: un modelo cronológico para el estudio de los yacimientos del Archipiélago Canario: XV Coloquio de Historia Canario-Americana p. 1999 - 2021.

Tite, M. S., I. C. Freestone, I. Mason, J. Molera, M. Vendrell, and N. Wood, 1998, Lead glazes in antiquity - Methods of production and reasons for use, Archaeometry, 40(2), $241-260$.

Vaz, E., J. J. LaBrecque, and J. M. Cruxent, 1997, Determination of the provenance of majolica ceramics from Europe by thermoluminiscence employing principal components, Fresenius' Journal of Analytical Chemistry, 358, 529 - 532. 
Weigand, P. C., G. Harbottle, and E. V. Sayre, 1977, Turquoise sources and source analysis: Mesoamerica and the Southwestern USA, in Exchange systems in prehistory, 15 - 34, T. K. Earle, and J. E. Ericson, eds., Academic Press, New York \& London. 


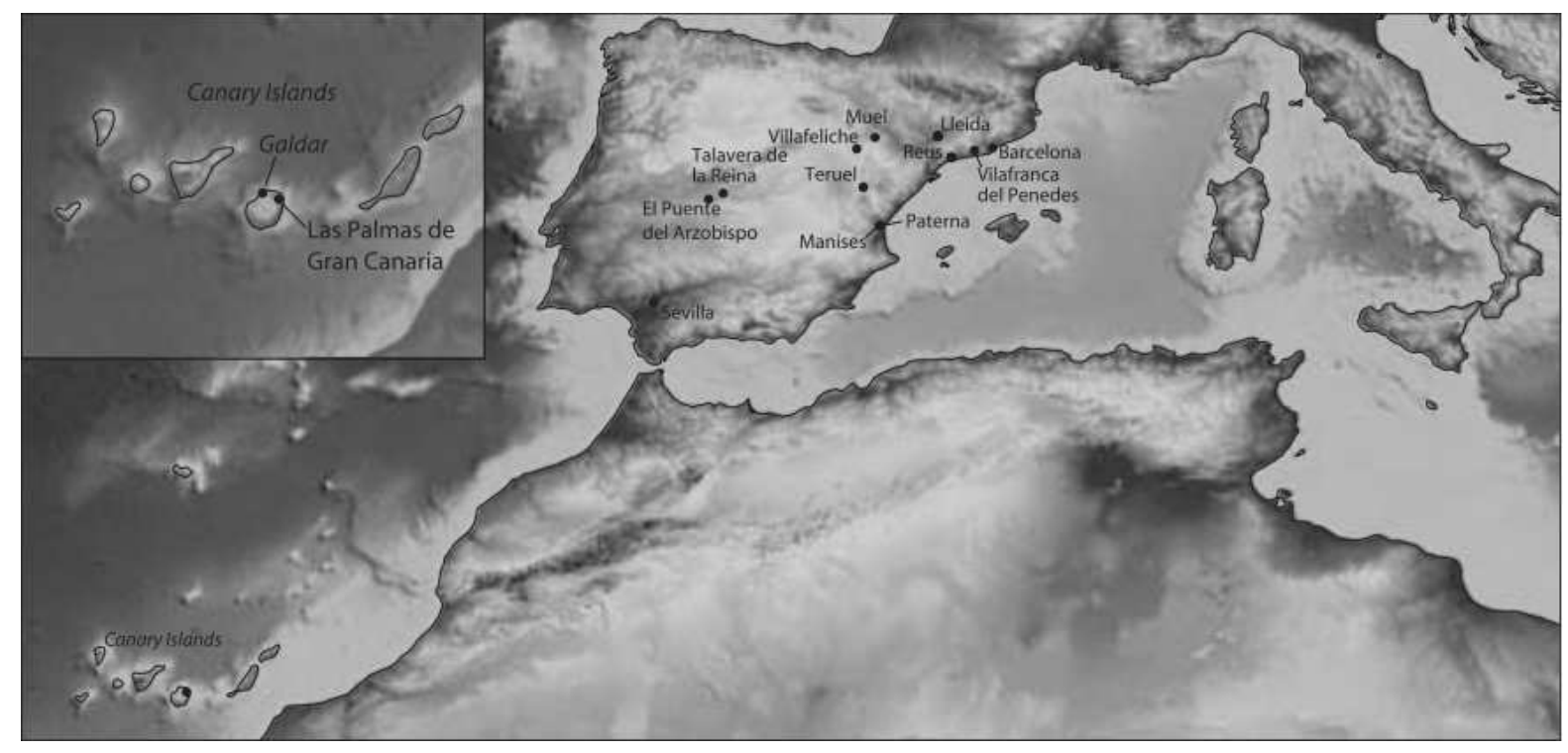

Figure 1. Map of the main sites cited in the text 


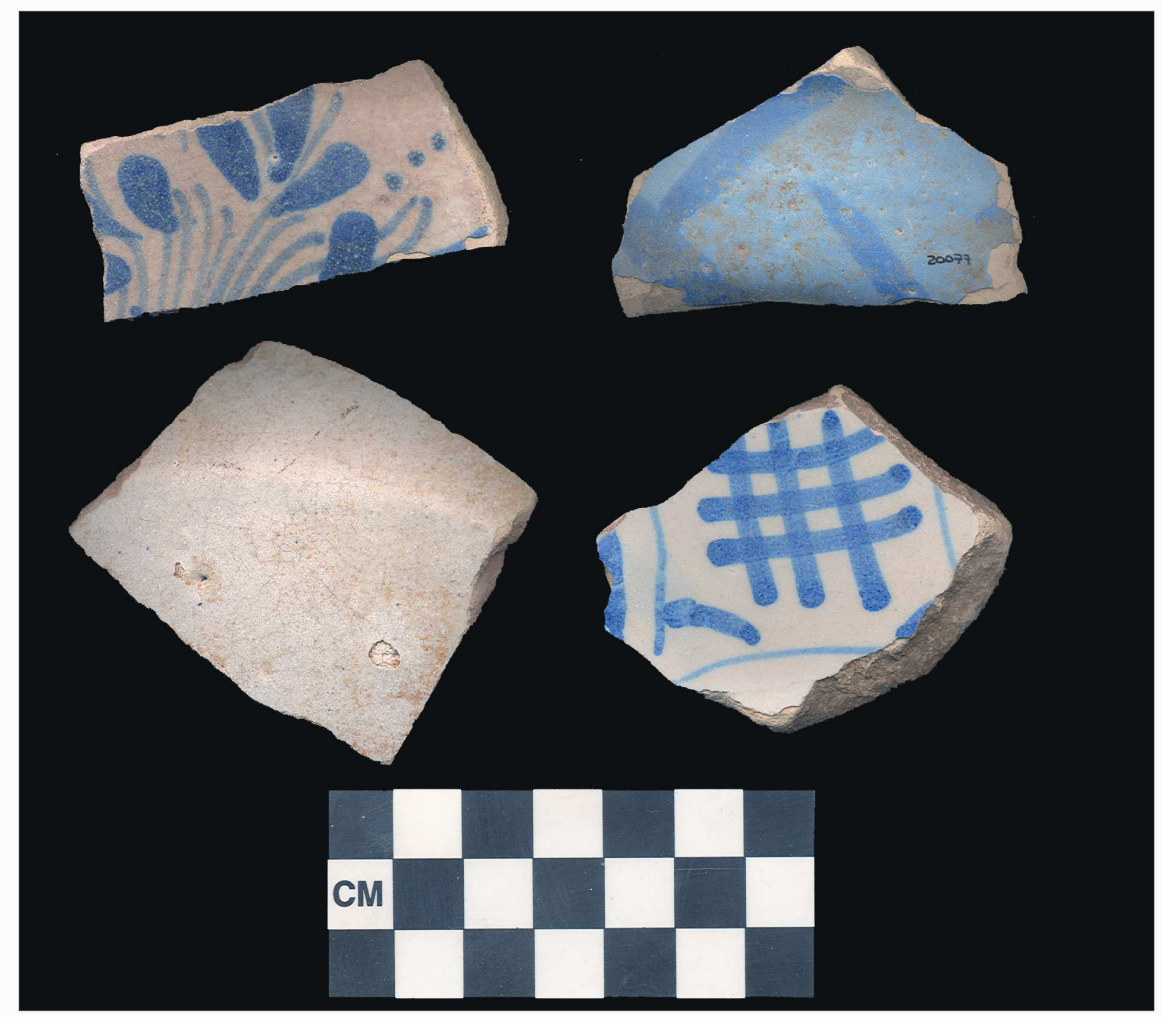

Figure 2. Examples of the majolica pottery from Gran Canaria island. From left to right and up to down: MJ0280, MJ0282, MJ0264 and MJ0274 


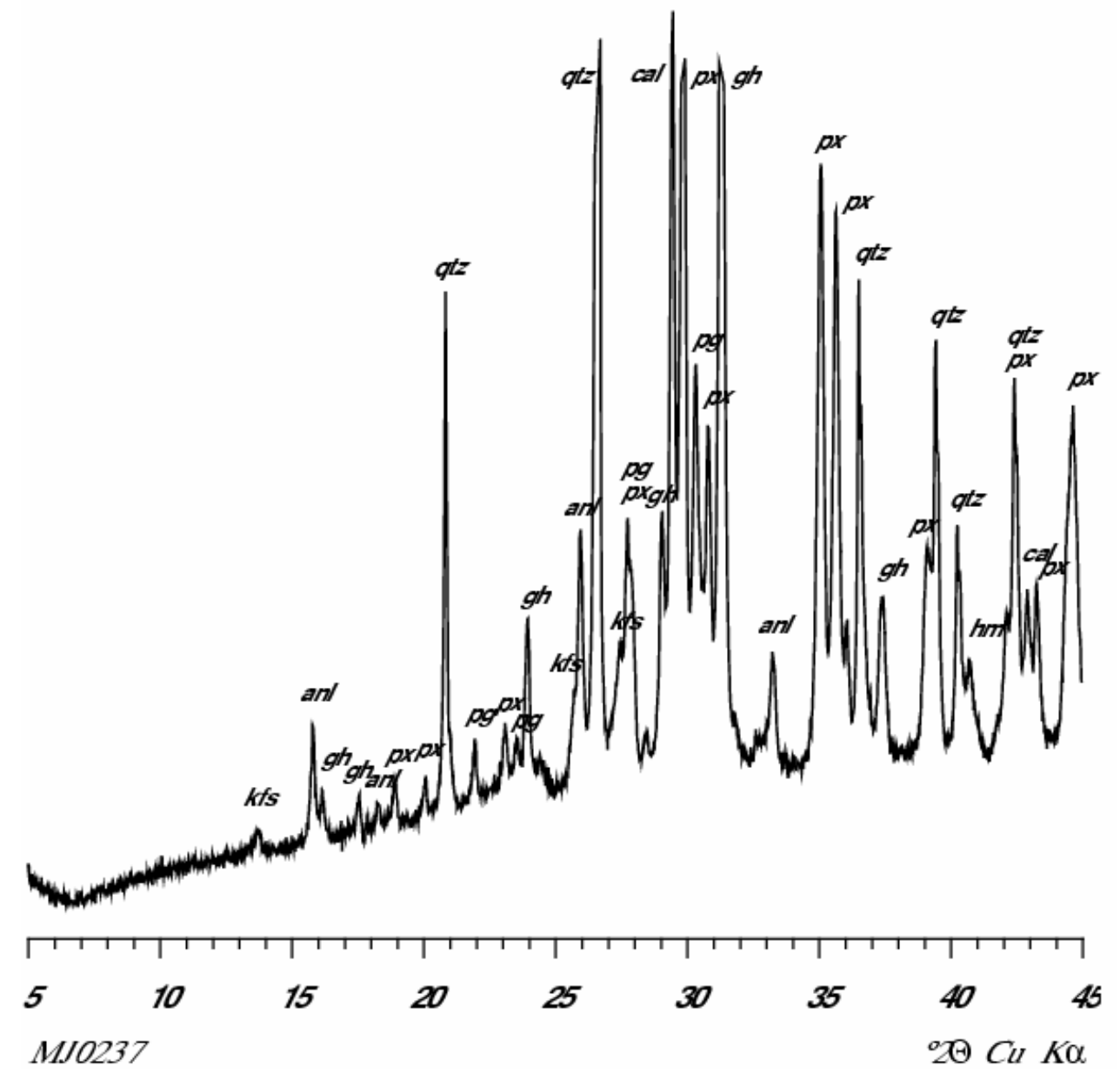

Figure 3. XRD Diffractogram of the sample MJ0237, representative of the affected pottery. anl: analcime; cal: calcite; gh: gehlenite; hm: hematite; ill: illite-muscovite; kfs: alkaline feldspar; pg: plagioclase; px: pyroxene; qtz: quartz 


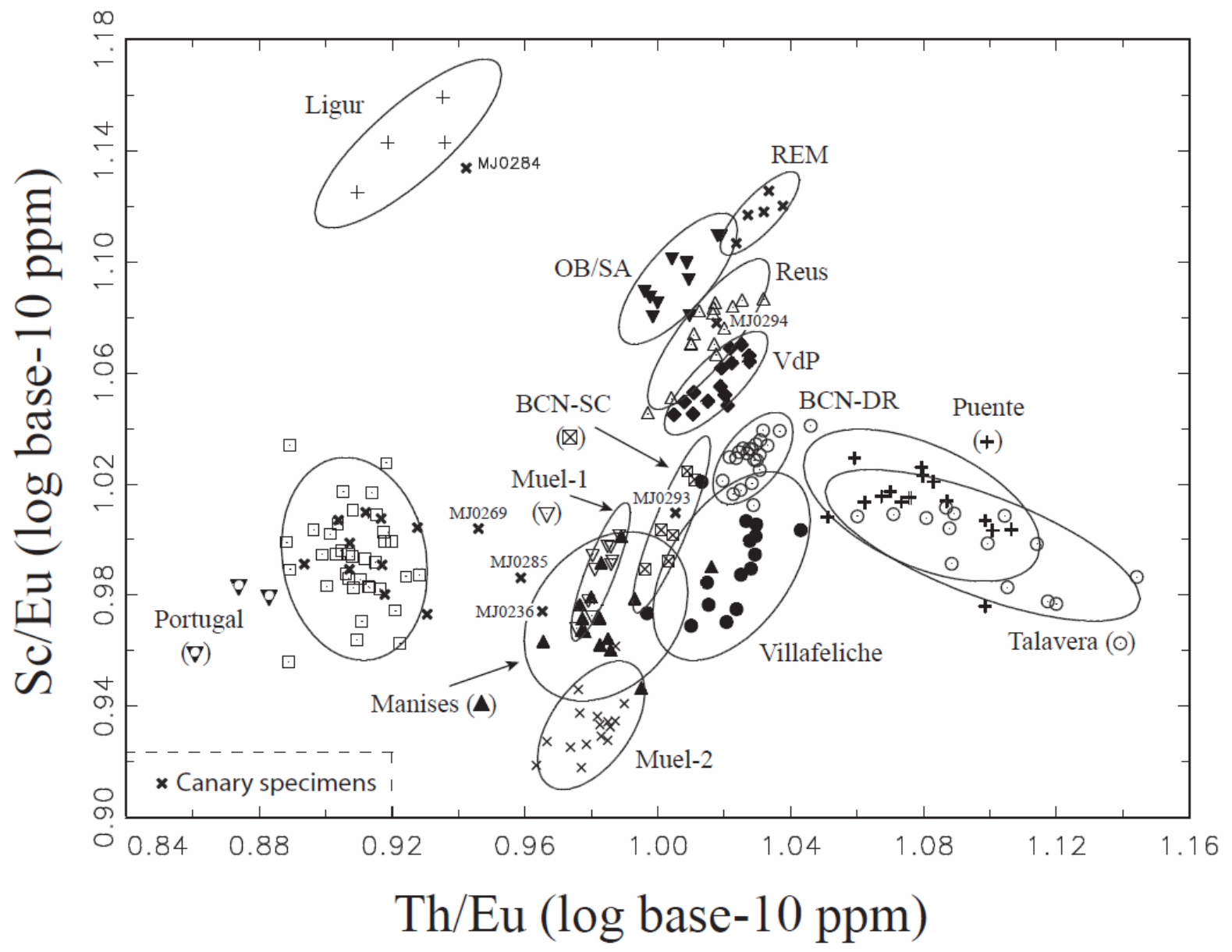

Figure 4. Bivariate plot using log base $10 \mathrm{Th} / \mathrm{Eu}$ and $\mathrm{Sc} / \mathrm{Eu}$ as variables showing the 15 reference compositional paste groups and the Canary individuals. Ellipses represent a confidence interval of $90 \%$ 


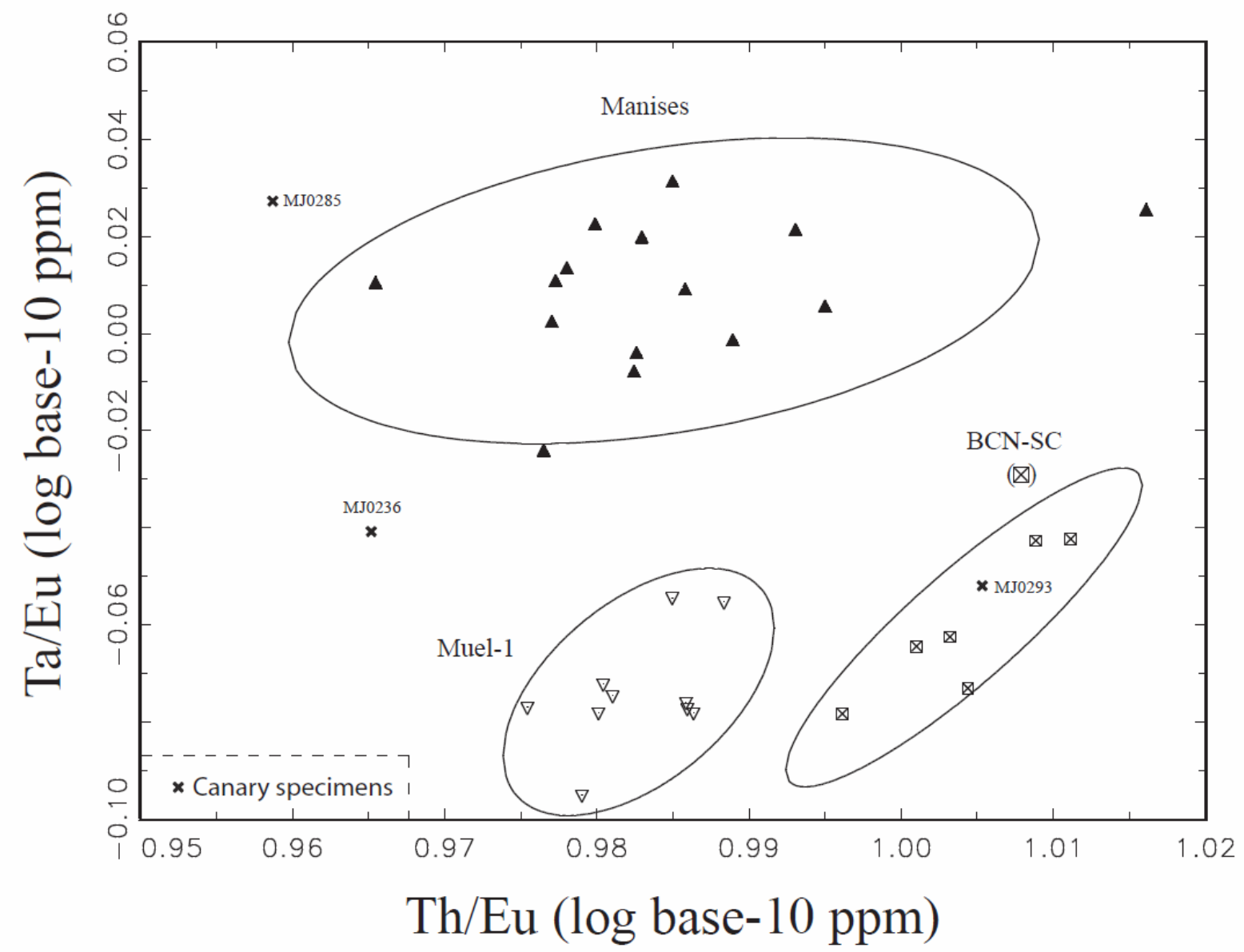

Figure 5. Bivariate plot using $\log$ base $10 \mathrm{Th} / \mathrm{Eu}$ and $\mathrm{Ta} / \mathrm{Eu}$ as variables showing the BCN-SC, Manises and Muel-1 group separation 


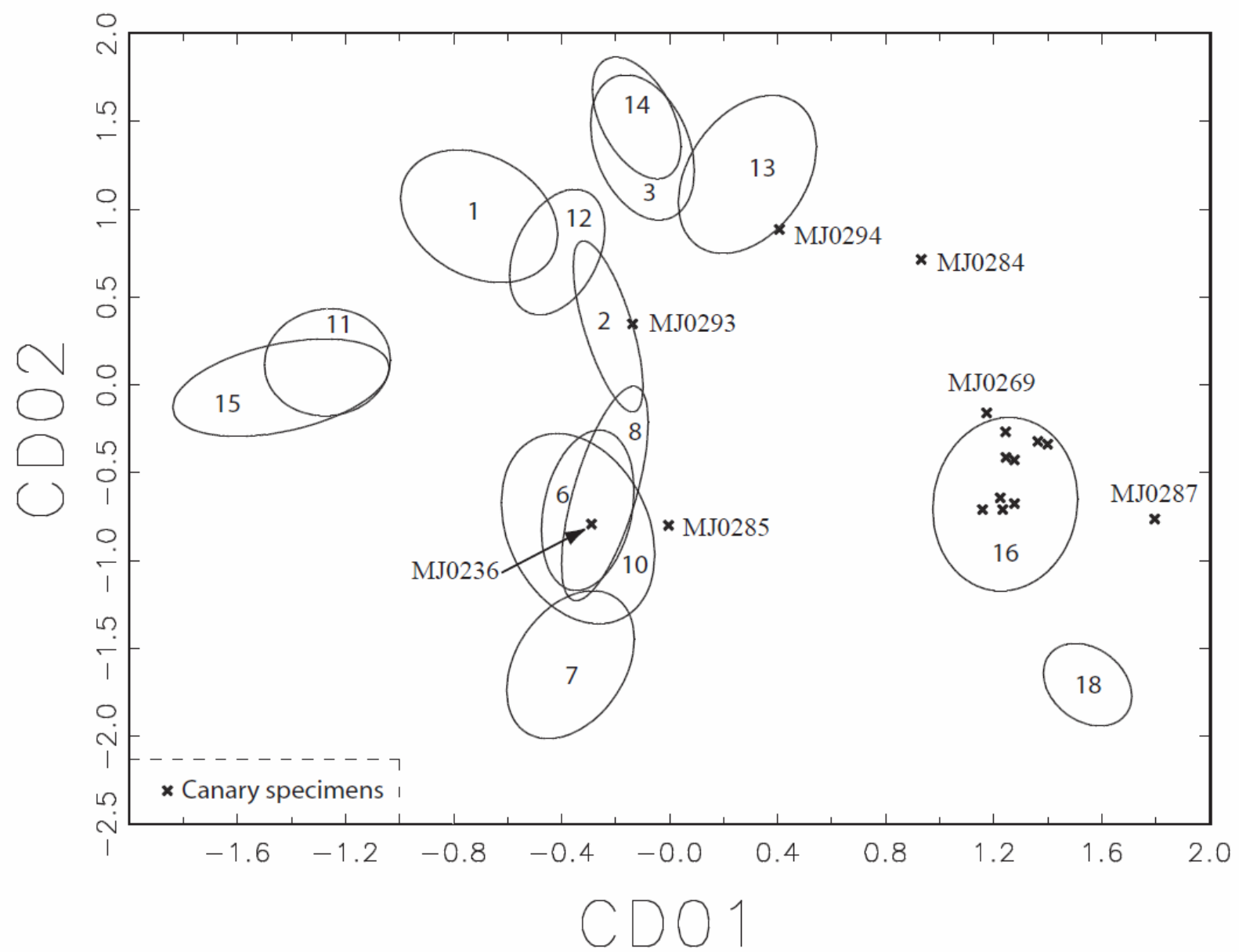

6. Bivariate plot using the first two Discriminant functions as variables showing the groups separation suggested by Canonical Discriminant Analysis: 1. BCN-DR; 2. BCNSC, 3. Reus; 4. Muel-1; 5. Muel-2; 6. Villafeliche, 7. Manises, 8. Puente del Arzobispo, 9. VdP; 10. OB/SA, 11. REM; 12. Talavera; 13. Sevilla; 14. Portugal; and individuals from the Canary Islands. Ligurian group is not represented because its high chemical differences compress the rest of the groups in the graphic representation. Ellipses represent a confidence interval of $90 \%$ 


\begin{tabular}{|c|c|c|c|c|c|c|c|c|c|c|c|}
\hline Sites & Centuries & Green \& Black & Green & Blue & Blue \& Green & Lusterware & White plain & Polychrome & Sgraffito & Non glazed & Total \\
\hline Barcelona & & - & - & 4 & - & 16 & - & - & - & - & 20 \\
\hline Drassanes & $16^{t h}-17^{\text {th }}$ & - & - & 4 & - & 9 & - & - & - & - & 13 \\
\hline H. Santa Creu & $16^{\text {th }}-17^{\text {th }}$ & - & - & - & - & 7 & - & - & - & - & 7 \\
\hline Lleida & & - & - & 11 & - & - & - & 1 & - & 3 & 15 \\
\hline Obradors & $16^{\text {th }}-17^{\text {th }}$ & - & - & 2 & - & - & - & 1 & - & 2 & 5 \\
\hline St. Anastasi & $16^{t h}-17^{t h}$ & - & - & 5 & - & - & - & - & - & - & 5 \\
\hline Remolins & $16^{\text {th }}-17^{\text {th }}$ & - & - & 4 & - & - & - & - & - & 1 & 5 \\
\hline Manises & $15^{\text {th }}$ & - & - & - & - & 15 & - & - & - & - & 15 \\
\hline Muel & $16^{\text {th }}-17^{\text {th }}$ & - & - & 16 & 10 & - & - & - & - & - & 26 \\
\hline Puente & $16^{\text {th }}-18$ th & - & - & 13 & - & - & - & 1 & - & 1 & 15 \\
\hline Reus & $16^{t h}-17^{t h}$ & - & - & - & - & 3 & 12 & - & - & - & 15 \\
\hline Sevilla & & - & - & 21 & - & 1 & 9 & 5 & - & - & 36 \\
\hline Pureza & $16^{\text {th }}-17^{\text {th }}$ & - & - & 3 & - & 1 & 5 & 3 & - & - & 12 \\
\hline Valladares & $16^{\text {th }}-17^{\text {th }}$ & - & - & 8 & - & - & 2 & - & - & - & 10 \\
\hline Plaza Armas & $16^{\text {th }}-17^{\text {th }}$ & - & - & 8 & - & - & 2 & - & - & - & 10 \\
\hline Museu Ceràmica & $15^{\text {th }}-16^{\text {th }}$ & - & - & 2 & - & - & - & 2 & - & - & 4 \\
\hline Talavera & & - & - & 13 & - & - & - & 1 & - & - & 14 \\
\hline Mirasol & $16^{\text {th }}-17^{\text {th }}$ & - & - & 12 & - & - & - & - & - & - & 12 \\
\hline Museu Ceràmica & $16^{t h}-17^{t h}$ & - & - & 1 & - & - & - & 1 & - & - & 2 \\
\hline Vilafranca & $16^{\text {th }}-17^{\text {th }}$ & - & - & 1 & - & 1 & 13 & - & - & - & 15 \\
\hline Villafeliche & $17^{\text {th }}-18^{\text {th }}$ & - & - & 15 & - & - & & - & - & - & 15 \\
\hline Canary Islands & & 1 & 1 & 9 & - & 3 & 6 & 1 & 1 & - & 22 \\
\hline Cueva Pintada & $15^{\text {th }}-16^{\text {th }}$ & - & 1 & - & - & 1 & 2 & - & - & - & 4 \\
\hline San Francisco & $16^{\text {th }}-17^{\text {th }}$ & 1 & - & 9 & - & 2 & 4 & 1 & 1 & - & 18 \\
\hline Total & & 1 & 1 & 103 & 10 & 39 & 40 & 9 & 1 & 4 & 208 \\
\hline
\end{tabular}

Table 1. Summary of the studied shards according to their decoration type and chronology and regarding to their production and reception archaeological sites 


\begin{tabular}{lccc}
\hline ANID & Description & Form & Date(s) \\
\hline MJ0236 & Lusterware & plate & 15 th-16th \\
MJ0237 & Sevillan White & plate & 15 th-16th \\
MJ0241 & Sevillan White & plate & 15 th-16th \\
MJ0253 & Green & tile & 15 th-16th \\
MJ0258 & Columbia Simple & bowl & 16 th-17th \\
MJ0262 & Sevillan White & bowl & 16 th-17th \\
MJ0268 & Isabela Polychrome & porringer & 16 th-17th \\
MJ0269 & Delft serie & plate & 16 th-17th \\
MJ0270 & Ligurian blue on white & plate & 16 th-17th \\
MJ0272 & Ligurian blue on white & plate & 16 th-17th \\
MJ0275 & Portuguese blue on white & plate & 16 th-17th \\
MJ0284 & Sgraffito & plate & 16 th-17th \\
MJ0285 & Lusterware & plate & 16 th-17th \\
MJ0286 & Lusterware & plate & 16 th-17th \\
MJ0287 & Columbia Simple & plate & 16 th-17th \\
MJ0288 & Sevillan White & plate & 16 th-17th \\
MJ0289 & Delft serie & plate & 16 th-17th \\
MJ0290 & Ligurian blue on white & plate & 16 th-17th \\
MJ0291 & Ligurian blue on white & plate & 16 th-17th \\
MJ0292 & Portuguese blue on white & plate & 16 th-17th \\
MJ0293 & Catalan blue on white & plate & 16 th-17th \\
MJ0294 & Green and Manganese & plate & 16 th \\
& & & \\
& & &
\end{tabular}

Table 2. Classification and description of samples from the Canary Islands 
$\begin{array}{llllllllllllllllllllllllllllllllllllllllllll}\text { Var.Matrix } & \mathrm{As} & \mathrm{La} & \mathrm{Lu} & \mathrm{Nd} & \mathrm{Sm} & \mathrm{U} & \mathrm{Yb} & \mathrm{Ce} & \mathrm{Cr} & \mathrm{Cs} & \mathrm{Eu} & \mathrm{Fe} & \mathrm{Hf} & \mathrm{Rb} & \mathrm{Sb} & \mathrm{Sc} & \mathrm{Sr} & \mathrm{Ta} & \mathrm{Tb} & \mathrm{Th} & \mathrm{Zn} & \mathrm{Zr} & \mathrm{Al} & \mathrm{Ba} & \mathrm{Ca} & \mathrm{Dy} & \mathrm{K} & \mathrm{Mn} & \mathrm{Na} & \mathrm{Ti} & \mathrm{V}\end{array}$ As $\quad \begin{array}{lllllllllllllllll} & 0.00 & 0.25 & 0.26 & 0.25 & 0.25 & 0.35 & 0.26 & 0.25 & 0.31 & 0.42 & 0.25 & 0.24 & 0.30 & 0.40 & 0.36 & 0.25\end{array}$ $\begin{array}{lllllllllllllllll}0.25 & 0.00 & 0.01 & 0.00 & 0.00 & 0.07 & 0.01 & 0.00 & 0.09 & 0.18 & 0.00 & 0.02 & 0.04 & 0.11 & 0.26 & 0.01\end{array}$ $\begin{array}{llllllllllllllll}0.26 & 0.01 & 0.00 & 0.01 & 0.01 & 0.05 & 0.01 & 0.01 & 0.09 & 0.21 & 0.01 & 0.03 & 0.04 & 0.13 & 0.28 & 0.02\end{array}$ $\begin{array}{llllllllllllllll}0.25 & 0.00 & 0.01 & 0.00 & 0.00 & 0.07 & 0.01 & 0.00 & 0.09 & 0.19 & 0.01 & 0.02 & 0.04 & 0.11 & 0.28 & 0.02\end{array}$ $\begin{array}{llllllllllllllll}0.25 & 0.00 & 0.01 & 0.00 & 0.00 & 0.06 & 0.00 & 0.00 & 0.09 & 0.19 & 0.00 & 0.02 & 0.03 & 0.12 & 0.28 & 0.02\end{array}$ $\begin{array}{llllllllllllllll}0.35 & 0.07 & 0.05 & 0.07 & 0.06 & 0.00 & 0.07 & 0.06 & 0.18 & 0.24 & 0.08 & 0.11 & 0.12 & 0.13 & 0.34 & 0.09\end{array}$ $\begin{array}{llllllllllllllll}0.26 & 0.01 & 0.01 & 0.01 & 0.00 & 0.07 & 0.00 & 0.00 & 0.09 & 0.20 & 0.01 & 0.02 & 0.03 & 0.12 & 0.28 & 0.02\end{array}$ $\begin{array}{llllllllllllllll}0.25 & 0.00 & 0.01 & 0.00 & 0.00 & 0.06 & 0.00 & 0.00 & 0.09 & 0.19 & 0.00 & 0.02 & 0.04 & 0.11 & 0.27 & 0.01\end{array}$ $\begin{array}{llllllllllllllll}0.31 & 0.09 & 0.09 & 0.09 & 0.09 & 0.18 & 0.09 & 0.09 & 0.00 & 0.33 & 0.07 & 0.04 & 0.13 & 0.28 & 0.30 & 0.04\end{array}$ $\begin{array}{llllllllllllllll}0.42 & 0.18 & 0.21 & 0.19 & 0.19 & 0.24 & 0.20 & 0.19 & 0.33 & 0.00 & 0.22 & 0.22 & 0.29 & 0.07 & 0.51 & 0.20\end{array}$ $\begin{array}{llllllllllllllll}0.25 & 0.00 & 0.01 & 0.01 & 0.00 & 0.08 & 0.01 & 0.00 & 0.07 & 0.22 & 0.00 & 0.01 & 0.03 & 0.14 & 0.26 & 0.01\end{array}$ $\begin{array}{llllllllllllllll}0.24 & 0.02 & 0.03 & 0.02 & 0.02 & 0.11 & 0.02 & 0.02 & 0.04 & 0.22 & 0.01 & 0.00 & 0.07 & 0.16 & 0.25 & 0.00\end{array}$ $\begin{array}{llllllllllllllll}0.30 & 0.04 & 0.04 & 0.04 & 0.03 & 0.12 & 0.03 & 0.04 & 0.13 & 0.29 & 0.03 & 0.07 & 0.00 & 0.20 & 0.32 & 0.07\end{array}$ $\begin{array}{llllllllllllllll}0.40 & 0.11 & 0.13 & 0.11 & 0.12 & 0.13 & 0.12 & 0.11 & 0.28 & 0.07 & 0.14 & 0.16 & 0.20 & 0.00 & 0.42 & 0.14\end{array}$ $\begin{array}{llllllllllllllll}0.36 & 0.26 & 0.28 & 0.28 & 0.28 & 0.34 & 0.28 & 0.27 & 0.30 & 0.51 & 0.26 & 0.25 & 0.32 & 0.42 & 0.00 & 0.25\end{array}$ $\begin{array}{llllllllllllllll}0.25 & 0.01 & 0.02 & 0.02 & 0.02 & 0.09 & 0.02 & 0.01 & 0.04 & 0.20 & 0.01 & 0.00 & 0.07 & 0.14 & 0.25 & 0.00\end{array}$ $\begin{array}{llllllllllllllll}0.53 & 0.29 & 0.28 & 0.30 & 0.29 & 0.29 & 0.31 & 0.29 & 0.22 & 0.70 & 0.26 & 0.26 & 0.32 & 0.61 & 0.49 & 0.26\end{array}$ $\begin{array}{llllllllllllllll}0.25 & 0.02 & 0.02 & 0.02 & 0.01 & 0.07 & 0.02 & 0.02 & 0.11 & 0.16 & 0.02 & 0.04 & 0.05 & 0.10 & 0.34 & 0.03\end{array}$ $\begin{array}{llllllllllllllll}0.25 & 0.01 & 0.01 & 0.01 & 0.01 & 0.07 & 0.01 & 0.01 & 0.09 & 0.20 & 0.01 & 0.02 & 0.04 & 0.12 & 0.28 & 0.02\end{array}$ $\begin{array}{llllllllllllllll}0.26 & 0.01 & 0.01 & 0.01 & 0.01 & 0.05 & 0.01 & 0.00 & 0.11 & 0.16 & 0.02 & 0.03 & 0.05 & 0.09 & 0.28 & 0.02\end{array}$ $\begin{array}{llllllllllllllll}0.30 & 0.07 & 0.07 & 0.07 & 0.07 & 0.15 & 0.07 & 0.07 & 0.08 & 0.25 & 0.06 & 0.04 & 0.14 & 0.19 & 0.27 & 0.04\end{array}$ $\begin{array}{llllllllllllllll}0.30 & 0.04 & 0.03 & 0.04 & 0.03 & 0.10 & 0.03 & 0.04 & 0.13 & 0.30 & 0.03 & 0.07 & 0.02 & 0.21 & 0.34 & 0.07\end{array}$ $\begin{array}{llllllllllllllll}0.24 & 0.01 & 0.02 & 0.01 & 0.01 & 0.07 & 0.02 & 0.01 & 0.07 & 0.16 & 0.01 & 0.01 & 0.07 & 0.11 & 0.28 & 0.01\end{array}$ $\begin{array}{llllllllllllllll}0.37 & 0.09 & 0.11 & 0.10 & 0.10 & 0.13 & 0.10 & 0.09 & 0.20 & 0.23 & 0.10 & 0.11 & 0.16 & 0.16 & 0.29 & 0.10\end{array}$ $\begin{array}{llllllllllllllll}0.36 & 0.16 & 0.14 & 0.16 & 0.15 & 0.20 & 0.16 & 0.15 & 0.17 & 0.46 & 0.14 & 0.16 & 0.18 & 0.40 & 0.41 & 0.15\end{array}$ $\begin{array}{llllllllllllllll}0.25 & 0.01 & 0.01 & 0.01 & 0.00 & 0.08 & 0.01 & 0.01 & 0.09 & 0.20 & 0.01 & 0.02 & 0.03 & 0.13 & 0.28 & 0.02\end{array}$ $\begin{array}{llllllllllllllll}0.37 & 0.07 & 0.09 & 0.08 & 0.08 & 0.11 & 0.09 & 0.07 & 0.21 & 0.16 & 0.09 & 0.11 & 0.14 & 0.06 & 0.39 & 0.10\end{array}$ $\begin{array}{llllllllllllllll}0.30 & 0.10 & 0.10 & 0.10 & 0.10 & 0.22 & 0.10 & 0.10 & 0.12 & 0.40 & 0.08 & 0.07 & 0.13 & 0.32 & 0.25 & 0.08\end{array}$ $\begin{array}{llllllllllllllll}0.55 & 0.37 & 0.34 & 0.37 & 0.36 & 0.48 & 0.35 & 0.37 & 0.27 & 0.70 & 0.34 & 0.30 & 0.39 & 0.68 & 0.53 & 0.31\end{array}$ $\begin{array}{llllllllllllllll}0.25 & 0.01 & 0.02 & 0.02 & 0.01 & 0.08 & 0.02 & 0.01 & 0.07 & 0.22 & 0.01 & 0.02 & 0.04 & 0.15 & 0.27 & 0.02\end{array}$ $\begin{array}{llllllllllllllll}0.26 & 0.05 & 0.06 & 0.06 & 0.06 & 0.14 & 0.06 & 0.05 & 0.05 & 0.24 & 0.04 & 0.02 & 0.12 & 0.20 & 0.25 & 0.02\end{array}$ $\begin{array}{lllllllllllllll}0.53 & 0.25 & 0.25 & 0.26 & 0.30 & 0.30 & 0.24 & 0.37 & 0.36 & 0.25 & 0.37 & 0.30 & 0.55 & 0.25 & 0.26\end{array}$ $\begin{array}{lllllllllllllll}0.29 & 0.02 & 0.01 & 0.01 & 0.07 & 0.04 & 0.01 & 0.09 & 0.16 & 0.01 & 0.07 & 0.10 & 0.37 & 0.01 & 0.05\end{array}$ $\begin{array}{lllllllllllllll}0.28 & 0.02 & 0.01 & 0.01 & 0.07 & 0.03 & 0.02 & 0.11 & 0.14 & 0.01 & 0.09 & 0.10 & 0.34 & 0.02 & 0.06\end{array}$ $\begin{array}{lllllllllllllll}0.30 & 0.02 & 0.01 & 0.01 & 0.07 & 0.04 & 0.01 & 0.10 & 0.16 & 0.01 & 0.08 & 0.10 & 0.37 & 0.02 & 0.06\end{array}$ $\begin{array}{lllllllllllllll}0.29 & 0.01 & 0.01 & 0.01 & 0.07 & 0.03 & 0.01 & 0.10 & 0.15 & 0.00 & 0.08 & 0.10 & 0.36 & 0.01 & 0.06\end{array}$ $\begin{array}{lllllllllllllll}0.29 & 0.07 & 0.07 & 0.05 & 0.15 & 0.10 & 0.07 & 0.13 & 0.20 & 0.08 & 0.11 & 0.22 & 0.48 & 0.08 & 0.14\end{array}$ $\begin{array}{lllllllllllllll}0.31 & 0.02 & 0.01 & 0.01 & 0.07 & 0.03 & 0.02 & 0.10 & 0.16 & 0.01 & 0.09 & 0.10 & 0.35 & 0.02 & 0.06\end{array}$ $\begin{array}{lllllllllllllll}0.29 & 0.02 & 0.01 & 0.00 & 0.07 & 0.04 & 0.01 & 0.09 & 0.15 & 0.01 & 0.07 & 0.10 & 0.37 & 0.01 & 0.05\end{array}$ $\begin{array}{lllllllllllllll}0.22 & 0.11 & 0.09 & 0.11 & 0.08 & 0.13 & 0.07 & 0.20 & 0.17 & 0.09 & 0.21 & 0.12 & 0.27 & 0.07 & 0.05\end{array}$ $\begin{array}{lllllllllllllll}0.70 & 0.16 & 0.20 & 0.16 & 0.25 & 0.30 & 0.16 & 0.23 & 0.46 & 0.20 & 0.16 & 0.40 & 0.70 & 0.22 & 0.24\end{array}$ $\begin{array}{lllllllllllllll}0.26 & 0.02 & 0.01 & 0.02 & 0.06 & 0.03 & 0.01 & 0.10 & 0.14 & 0.01 & 0.09 & 0.08 & 0.34 & 0.01 & 0.04\end{array}$ $\begin{array}{lllllllllllllll}0.26 & 0.04 & 0.02 & 0.03 & 0.04 & 0.07 & 0.01 & 0.11 & 0.16 & 0.02 & 0.11 & 0.07 & 0.30 & 0.02 & 0.02\end{array}$ $\begin{array}{lllllllllllllll}0.32 & 0.05 & 0.04 & 0.05 & 0.14 & 0.02 & 0.07 & 0.16 & 0.18 & 0.03 & 0.14 & 0.13 & 0.39 & 0.04 & 0.12\end{array}$ $\begin{array}{lllllllllllllll}0.61 & 0.10 & 0.12 & 0.09 & 0.19 & 0.21 & 0.11 & 0.16 & 0.40 & 0.13 & 0.06 & 0.32 & 0.68 & 0.15 & 0.20\end{array}$ $\begin{array}{lllllllllllllll}0.49 & 0.34 & 0.28 & 0.28 & 0.27 & 0.34 & 0.28 & 0.29 & 0.41 & 0.28 & 0.39 & 0.25 & 0.53 & 0.27 & 0.25\end{array}$ $\begin{array}{lllllllllllllll}0.26 & 0.03 & 0.02 & 0.02 & 0.04 & 0.07 & 0.01 & 0.10 & 0.15 & 0.02 & 0.10 & 0.08 & 0.31 & 0.02 & 0.02\end{array}$ $\begin{array}{lllllllllllllll}0.00 & 0.33 & 0.30 & 0.32 & 0.34 & 0.29 & 0.28 & 0.39 & 0.17 & 0.29 & 0.46 & 0.31 & 0.42 & 0.26 & 0.25\end{array}$ $\begin{array}{lllllllllllllll}0.33 & 0.00 & 0.02 & 0.01 & 0.10 & 0.05 & 0.02 & 0.13 & 0.18 & 0.02 & 0.08 & 0.16 & 0.41 & 0.03 & 0.08\end{array}$ $\begin{array}{lllllllllllllll}0.30 & 0.02 & 0.00 & 0.01 & 0.07 & 0.04 & 0.02 & 0.11 & 0.16 & 0.01 & 0.09 & 0.10 & 0.35 & 0.02 & 0.06\end{array}$ $\begin{array}{lllllllllllllll}0.32 & 0.01 & 0.01 & 0.00 & 0.07 & 0.05 & 0.01 & 0.09 & 0.18 & 0.01 & 0.06 & 0.12 & 0.40 & 0.03 & 0.06\end{array}$ $\begin{array}{lllllllllllllllll}0.34 & 0.10 & 0.07 & 0.07 & 0.00 & 0.14 & 0.06 & 0.15 & 0.18 & 0.07 & 0.17 & 0.09 & 0.25 & 0.07 & 0.05\end{array}$ $\begin{array}{lllllllllllllll}0.29 & 0.05 & 0.04 & 0.05 & 0.14 & 0.00 & 0.07 & 0.16 & 0.17 & 0.03 & 0.14 & 0.13 & 0.38 & 0.04 & 0.12\end{array}$ $\begin{array}{lllllllllllllll}0.28 & 0.02 & 0.02 & 0.01 & 0.06 & 0.07 & 0.00 & 0.10 & 0.17 & 0.02 & 0.07 & 0.12 & 0.38 & 0.02 & 0.04\end{array}$ $\begin{array}{lllllllllllllll}0.39 & 0.13 & 0.11 & 0.09 & 0.15 & 0.16 & 0.10 & 0.00 & 0.26 & 0.11 & 0.12 & 0.18 & 0.50 & 0.11 & 0.13\end{array}$ $\begin{array}{lllllllllllllll}0.17 & 0.18 & 0.16 & 0.18 & 0.18 & 0.17 & 0.17 & 0.26 & 0.00 & 0.15 & 0.31 & 0.17 & 0.26 & 0.14 & 0.16\end{array}$ $\begin{array}{lllllllllllllll}0.29 & 0.02 & 0.01 & 0.01 & 0.07 & 0.03 & 0.02 & 0.11 & 0.15 & 0.00 & 0.09 & 0.10 & 0.35 & 0.02 & 0.06\end{array}$ $\begin{array}{lllllllllllllll}0.46 & 0.08 & 0.09 & 0.06 & 0.17 & 0.14 & 0.07 & 0.12 & 0.31 & 0.09 & 0.00 & 0.25 & 0.67 & 0.10 & 0.15\end{array}$ $\begin{array}{lllllllllllllll}0.31 & 0.16 & 0.10 & 0.12 & 0.09 & 0.13 & 0.12 & 0.18 & 0.17 & 0.10 & 0.25 & 0.00 & 0.23 & 0.10 & 0.09\end{array}$ $\begin{array}{lllllllllllllll}0.42 & 0.41 & 0.35 & 0.40 & 0.25 & 0.38 & 0.38 & 0.50 & 0.26 & 0.35 & 0.67 & 0.23 & 0.00 & 0.33 & 0.29\end{array}$ $\begin{array}{lllllllllllllll}0.26 & 0.03 & 0.02 & 0.03 & 0.07 & 0.04 & 0.02 & 0.11 & 0.14 & 0.02 & 0.10 & 0.10 & 0.33 & 0.00 & 0.05\end{array}$ $\begin{array}{lllllllllllllllllllllllllllllll}9.25 & 2.35 & 2.51 & 2.44 & 2.36 & 4.26 & 2.48 & 2.34 & 4.20 & 8.19 & 2.35 & 2.52 & 3.62 & 6.16 & 9.60 & 2.41 & 10.11 & 2.90 & 2.53 & 2.53 & 3.73 & 3.60 & 2.49 & 4.95 & 6.22 & 2.46 & 4.98 & 4.70 & 11.96 & 2.56 & 3.28\end{array}$

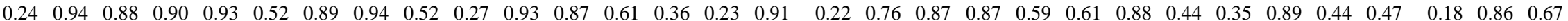
$\begin{array}{lllllllllllllllllllllllllllllll}0.94 & 0.99 & 0.99 & 0.99 & 0.99 & 0.95 & 0.99 & 0.99 & 0.88 & 0.85 & 1.00 & 0.99 & 0.98 & 0.83 & 0.88 & 0.99 & 0.66 & 0.97 & 0.99 & 0.97 & 0.94 & 0.97 & 0.98 & 0.95 & 0.70 & 0.99 & 0.89 & 0.82 & 0.55 & 1.00 & 0.95\end{array}$ 2.19 
Table 3. Compositional variation matrix from the majolica production centers from the Iberian Peninsula and the reception centers from the Canary Islands. In each column $\mathrm{i}(\mathrm{i}=1, \ldots, \mathrm{S})$ are the variances after a logratio transformation using the component $\mathrm{x}_{\mathrm{i}}$ as divisor. vt= total variation. $\tau_{\mathrm{i}}=$ total sum of variances in column $\mathrm{i} . \mathrm{vt} / \tau_{\mathrm{i}}=$ percentage of variance in the logratio covariance matrix using the component $\mathrm{x}_{\mathrm{i}}$ as divisor due to the total variation. $r_{v . \tau}=$ correlation between the values $\tau_{\mathrm{ij}}(\mathrm{i} \neq \mathrm{j})$ and the corresponding values $\tau_{\mathrm{i}}(\mathrm{j}=1, \ldots, \mathrm{i}-1, \mathrm{i}+1, \ldots \mathrm{S})$ 


\begin{tabular}{|c|c|c|c|c|c|c|c|c|c|c|c|c|c|c|c|c|c|c|c|}
\hline \multirow{2}{*}{$\begin{array}{l}\text { Groups } \\
\text { Elements }\end{array}$} & $\begin{array}{c}\text { BCN-DR } \\
(n=14)\end{array}$ & $\begin{array}{c}\text { BCN-SC } \\
(n=7)\end{array}$ & \multicolumn{2}{|c|}{$\begin{array}{l}\text { Ligur } \\
(n=4)\end{array}$} & $\begin{array}{c}\text { Manises } \\
(n=17)\end{array}$ & \multicolumn{2}{|c|}{$\begin{array}{l}\text { Muel-1 } \\
(n=10)\end{array}$} & \multicolumn{2}{|c|}{$\begin{array}{c}\text { Muel-2 } \\
(n=15)\end{array}$} & \multicolumn{2}{|c|}{$\begin{array}{l}\mathrm{OB} / \mathrm{SA} \\
(\mathrm{n}=10)\end{array}$} & \multicolumn{2}{|c|}{$\begin{array}{l}\text { Portugal } \\
(n=2)\end{array}$} & \multicolumn{2}{|c|}{$\begin{array}{l}\text { Puente } \\
(n=15)\end{array}$} & \multicolumn{2}{|c|}{$\begin{array}{l}\text { REM } \\
(n=5)\end{array}$} & \multicolumn{2}{|c|}{$\begin{array}{c}\text { Reus } \\
(n=15)\end{array}$} \\
\hline & Mean sd & Mean sd & Mean & sd & Mean sd & Mean & sd & Mean & sd & Mean & sd & Mean & sd & Mean & sd & Mean & sd & Mean & sd \\
\hline As (ppm) & $23 \pm 13$ & $34 \pm 15$ & 16 & \pm 7 & $19 \pm 1$ & 30 & \pm 9 & 16 & \pm 2 & 26 & \pm 11 & 33 & \pm 10 & 22 & \pm 2 & 39 & \pm 8 & 16 & \pm 2 \\
\hline La (ppm) & $38 \pm 1$ & $36 \pm 2$ & 27 & \pm 1 & $36 \pm 1$ & 40 & \pm 1 & 38 & \pm 1 & 35 & \pm 3 & 27 & \pm 2 & 38 & \pm 1 & 42 & \pm 0 & 30 & \pm 1 \\
\hline Lu (ppm) & $0.4 \pm 0.0$ & $0.4 \pm 0.0$ & 0.3 & \pm 0.0 & $0.4 \pm 0.0$ & 0.4 & \pm 0.0 & 0.4 & \pm 0.0 & 0.4 & \pm 0.0 & 0.3 & \pm 0.0 & 0.5 & \pm 0.0 & 0.4 & \pm 0.0 & 0.3 & \pm 0.0 \\
\hline Nd (ppm) & $33 \pm 2$ & $31 \pm 3$ & 24 & \pm 1 & $31 \pm 1$ & 35 & \pm 2 & 32 & \pm 2 & 28 & \pm 2 & 25 & \pm 2 & 35 & \pm 1 & 33 & \pm 1 & 26 & \pm 2 \\
\hline Sm (ppm) & $7 \pm 0$ & $6 \pm 0$ & & \pm 0 & $6 \pm 0$ & 7 & \pm 0 & & \pm 0 & & \pm 0 & 5 & \pm 0 & & \pm 0 & & \pm 0 & & \pm 0 \\
\hline U (ppm) & $3 \pm 0$ & $3 \pm 0$ & & \pm 0 & $3 \pm 0$ & & \pm 0 & & \pm 0 & & \pm 0 & 3 & \pm 0 & & \pm 0 & & \pm 1 & 3 & \pm 1 \\
\hline $\mathrm{Yb}(p p m)$ & $3 \pm 0$ & $3 \pm 0$ & 2 & \pm 0 & $3 \pm 0$ & & \pm 0 & & \pm 0 & & \pm 0 & & \pm 0 & & \pm 0 & & \pm 0 & & \pm 0 \\
\hline $\mathrm{Ce}$ (ppm) & $76 \pm 3$ & $72 \pm 4$ & 55 & \pm 3 & $70 \pm 2$ & 80 & \pm 2 & 78 & \pm 3 & 70 & \pm 6 & 56 & \pm 4 & 80 & \pm 2 & 84 & \pm 1 & 60 & \pm 3 \\
\hline Co (ppm) & $17 \pm 6$ & $17 \pm 3$ & 31 & \pm 11 & $15 \pm 2$ & 20 & \pm 1 & 20 & \pm 2 & 24 & \pm 4 & 18 & \pm 8 & 14 & \pm 1 & 31 & \pm 7 & 15 & \pm 2 \\
\hline $\mathrm{Cr}$ (ppm) & $67 \pm 4$ & $62 \pm 6$ & 301 & \pm 28 & $64 \pm 3$ & 75 & \pm 3 & 57 & \pm 4 & 90 & \pm 7 & 80 & \pm 4 & 58 & \pm 3 & 106 & \pm 3 & 72 & \pm 5 \\
\hline Cs (ppm) & $18 \pm 2$ & $6 \pm 2$ & 4 & \pm 1 & $9 \pm 1$ & 8 & \pm 0 & & \pm 0 & 8 & \pm 1 & 3 & \pm 0 & 12 & \pm 0 & 11 & \pm 1 & 15 & \pm 3 \\
\hline Eu (ppm) & $1.2 \pm 0.0$ & $1.2 \pm 0.1$ & 1.0 & \pm 0.0 & $1.2 \pm 0.0$ & 1.4 & \pm 0.0 & 1.3 & \pm 0.0 & 1.2 & \pm 0.1 & 1.1 & \pm 0.1 & 1.2 & \pm 0.0 & 1.4 & \pm 0.0 & 1.0 & \pm 0.0 \\
\hline $\mathrm{Fe}(\%)$ & $3.41 \pm 0.14$ & $3.13 \pm 0.22$ & 4.04 & \pm 0.24 & $3.20 \pm 0.13$ & 3.83 & \pm 0.23 & 2.99 & \pm 0.08 & 3.99 & \pm 0.35 & 2.77 & \pm 0.08 & 3.55 & \pm 0.19 & 5.01 & \pm 0.08 & 2.98 & \pm 0.11 \\
\hline Hf (ppm) & $5 \pm 0$ & $5 \pm 0$ & 4 & \pm 1 & $5 \pm 0$ & 5 & \pm 0 & & \pm 0 & & \pm 0 & 5 & \pm 1 & & \pm 0 & & \pm 0 & 3 & \pm 0 \\
\hline $\mathrm{Ni}$ (ppm) & $32 \pm 26$ & $16 \pm 26$ & 204 & \pm 13 & $37 \pm 13$ & 34 & \pm 21 & 14 & \pm 20 & 42 & \pm 23 & 0 & \pm 0 & 17 & \pm 20 & 58 & \pm 35 & 33 & \pm 23 \\
\hline $\mathbf{R b}(\mathrm{ppm})$ & $222 \pm 24$ & $111 \pm 20$ & 60 & \pm 33 & $129 \pm 10$ & 133 & \pm 6 & 116 & \pm 5 & 118 & \pm 17 & 50 & \pm 13 & 165 & \pm 9 & 169 & \pm 8 & 113 & \pm 12 \\
\hline $\mathbf{R b}(\mathrm{ppm})^{*}$ & $227 \pm 21$ & & & & & & & 114 & \pm 2 & & & & & & & & & 116 & \pm 12 \\
\hline Sb (ppm) & $4 \pm 3$ & $5 \pm 5$ & 2 & \pm 1 & $1 \pm 0$ & 4 & \pm 0 & 3 & \pm 0 & & \pm 2 & 1 & \pm 0 & & \pm 1 & & \pm 0 & & \pm 1 \\
\hline Sc (ppm) & $13 \pm 1$ & $12 \pm 1$ & 14 & \pm 1 & $11 \pm 0$ & 14 & \pm 0 & 11 & \pm 0 & 14 & \pm 1 & 10 & \pm 1 & 13 & \pm 1 & 19 & \pm 0 & 12 & \pm 1 \\
\hline $\mathrm{Sr}(\mathrm{ppm})$ & $159 \pm 43$ & $215 \pm 27$ & 676 & \pm 180 & $357 \pm 41$ & 373 & \pm 45 & 315 & \pm 33 & 606 & \pm 51 & 359 & \pm 16 & 354 & \pm 46 & 750 & \pm 213 & 496 & \pm 70 \\
\hline Ta ( & $1.2 \pm 0.1$ & $1.0 \pm 0.1$ & 0.9 & \pm 0.1 & $1.2 \pm 0.1$ & 1.2 & \pm 0.0 & 1.1 & \pm 0.0 & 1.2 & \pm 0.1 & 1.4 & \pm 0.1 & 1.5 & \pm 0 & 1.3 & \pm 0.0 & 0.9 & \pm 0.0 \\
\hline Tb (ppm) & $0.9 \pm 0.1$ & $0.8 \pm 0.1$ & 0.8 & \pm 0.0 & $0.8 \pm 0.1$ & 0.9 & \pm 0.1 & 0.9 & \pm 0.1 & 0.8 & \pm 0.0 & 0.6 & \pm 0.1 & 1.0 & \pm 0.2 & 1.0 & \pm 0.1 & 0.7 & \pm 0.1 \\
\hline Th (ppm) & $13 \pm 0$ & $12 \pm 1$ & & \pm 1 & $11 \pm 0$ & 13 & \pm 0 & 12 & \pm 0 & 12 & \pm 1 & 8 & \pm 1 & & \pm 0 & 15 & \pm 0 & 10 & \pm 0 \\
\hline Zn (ppm) & $120 \pm 24$ & $94 \pm 11$ & 108 & \pm 6 & $70 \pm 11$ & 85 & \pm 16 & 63 & \pm 4 & 103 & \pm 12 & 66 & \pm 6 & & \pm 5 & 138 & \pm 13 & & \pm 12 \\
\hline $\mathrm{Zr}(\mathrm{ppm})$ & $122 \pm 17$ & $129 \pm 22$ & 120 & \pm 10 & $135 \pm 15$ & 144 & \pm 22 & 170 & \pm 12 & 112 & \pm 12 & 146 & \pm 11 & 161 & \pm 13 & 113 & \pm 12 & 92 & \pm 19 \\
\hline Al (\%) & $7.43 \pm 0.32$ & $6.73 \pm 0.45$ & 6.66 & \pm 0.29 & $6.86 \pm 0.34$ & 7.96 & \pm 0.17 & 6.55 & \pm 0.25 & 8.23 & \pm 0.78 & 5.76 & \pm 0.42 & 8.21 & \pm 0.43 & 9.34 & \pm 0.92 & 6.82 & \pm 0.33 \\
\hline $\mathrm{Ba}(\mathrm{ppm})$ & $516 \pm 164$ & $374 \pm 28$ & 239 & \pm 63 & $342 \pm 26$ & 596 & \pm 63 & 530 & \pm 46 & 362 & \pm 68 & 160 & \pm 0 & 407 & \pm 39 & 513 & \pm 28 & 602 & \pm 633 \\
\hline $\mathrm{Ba}(\mathrm{ppm}) \dagger$ & $474 \pm 51$ & & & & & & & & & & & & & & & & & 439 & \pm 43 \\
\hline $\mathrm{Ca}(\%)$ & $11.05 \pm 0.93$ & $16.77 \pm 1.35$ & 12.50 & \pm 3.17 & $15.88 \pm 0.97$ & 11.21 & \pm 0.57 & 10.74 & \pm 0.35 & 14.37 & \pm 1.61 & 19.93 & \pm 0.80 & 12.63 & \pm 0.74 & 8.89 & \pm 0.42 & 17.82 & \pm 0.76 \\
\hline Dy (ppm) & $5 \pm 0$ & $4 \pm 0$ & 4 & \pm 0 & $4 \pm 0$ & 5 & \pm 0 & 5 & \pm 0 & 4 & \pm 0 & 3 & \pm 0 & & \pm 0 & 5 & \pm 0 & & \pm 0 \\
\hline$K(\%)$ & $2.45 \pm 0.82$ & $1.89 \pm 0.30$ & 1.32 & \pm 0.49 & $2.43 \pm 0.17$ & 2.65 & \pm 0.26 & 2.51 & \pm 0.18 & 2.18 & \pm 0.31 & 0.96 & \pm 0.35 & 2.37 & \pm 0.19 & 2.92 & \pm 0.53 & 1.95 & \pm 0.28 \\
\hline K (\% & $3.18 \pm 0.35$ & & & & & & & 2.59 & \pm 0.17 & & & & & & & & & 2.14 & \pm 0.22 \\
\hline Mn (ppm) & $553 \pm 38$ & $501 \pm 23$ & 486 & \pm 92 & $481 \pm 5$ & 654 & \pm 7 & 571 & \pm 38 & 651 & \pm 2 & 246 & \pm 4 & 520 & \pm 2 & 657 & \pm 16 & 420 & \pm 51 \\
\hline $\mathrm{Na}(\%)$ & $0.64 \pm 0.41$ & $0.33 \pm 0.06$ & 0.94 & \pm 0.14 & $0.25 \pm 0.04$ & 0.31 & \pm 0.09 & 0.26 & \pm 0.04 & 0.39 & \pm 0.08 & 0.74 & \pm 0.24 & 0.37 & \pm 0.04 & 0.77 & \pm 0.25 & 0.42 & \pm 0.09 \\
\hline $\mathrm{Na}(\%)^{\star}$ & $0.33 \pm 0.13$ & & & & & & & 0.25 & \pm 0.04 & & & & & & & & & 0.37 & \pm 0.07 \\
\hline $\mathrm{Ti}(\%)$ & $0.36 \pm 0.04$ & $0.35 \pm 0.02$ & 0.35 & \pm 0.02 & $0.33 \pm 0.02$ & 0.39 & \pm 0.04 & 0.38 & \pm 0.04 & 0.39 & \pm 0.05 & 0.45 & \pm 0.02 & 0.38 & \pm 0.04 & 0.37 & \pm 0.04 & 0.32 & \pm 0.02 \\
\hline$V(p p m)$ & $93 \pm 7$ & $87 \pm 15$ & 104 & \pm 7 & $85 \pm 16$ & 95 & \pm 8 & 67 & \pm 6 & 127 & \pm 10 & 58 & \pm 1 & 80 & \pm 8 & 167 & \pm 12 & 98 & \pm 9 \\
\hline
\end{tabular}

${ }^{*}=$ Values for those groups without taking into account samples showing analcime in their diffractograms $t=B a$ values for those groups which include samples with aberrant $\mathrm{Ba}$ contents 


\begin{tabular}{|c|c|c|c|c|c|c|c|c|c|c|}
\hline Groups & $\begin{array}{l}\text { Sevilla } \\
(n=36)\end{array}$ & $\begin{array}{c}\text { Talavera } \\
(n=14)\end{array}$ & $\begin{array}{l}\mathrm{VdP} \\
(n=15)\end{array}$ & $\begin{array}{l}\text { Villafeliche } \\
\quad(n=13)\end{array}$ & $\begin{array}{c}\text { MJ0269 } \\
\text { (Delft) }\end{array}$ & $\begin{array}{c}\text { MJ0284 } \\
\text { (Sgraffito) }\end{array}$ & MJ0287 & MJ0288 & MJ0293 & MJ0294 \\
\hline Elements & Mean sd & Mean sd & Mean sd & Mean sd & \multicolumn{6}{|c|}{ Composition } \\
\hline As (ppm) & $18 \pm 11$ & $22 \pm 10$ & $19 \pm 4$ & $11 \pm 6$ & 12 & 6 & 11 & 12 & 25 & 6 \\
\hline La (ppm) & $31 \pm 2$ & $39 \pm 2$ & $42 \pm 1$ & $39 \pm 2$ & 24 & 40 & 31 & 30 & 35 & 35 \\
\hline Lu (ppm) & $0.3 \pm 0.0$ & $0.4 \pm 0.0$ & $0.4 \pm 0.0$ & $0.4 \pm 0.0$ & 0.3 & 0.4 & 0.4 & 0.3 & 0.4 & 0.4 \\
\hline Nd (ppm) & $26 \pm 2$ & $36 \pm 3$ & $37 \pm 2$ & $32 \pm 2$ & 21 & 34 & 27 & 27 & 31 & 28 \\
\hline Sm (ppm) & $6 \pm 0$ & $7 \pm 0$ & $7 \pm 0$ & $7 \pm 0$ & 4 & 6 & 6 & 5 & 6 & 6 \\
\hline $\mathrm{U}(\mathrm{ppm})$ & $2 \pm 0$ & $5 \pm 0$ & $4 \pm 0$ & $7 \pm 1$ & 2 & 2 & 3 & 3 & 2 & 3 \\
\hline Yb (ppm) & $2 \pm 0$ & $3 \pm 0$ & $3 \pm 0$ & $3 \pm 0$ & 2 & 2 & 3 & 2 & 3 & 2 \\
\hline $\mathrm{Ce}$ (ppm) & $62 \pm 3$ & $80 \pm 4$ & $84 \pm 2$ & $81 \pm 2$ & 49 & 84 & 63 & 59 & 71 & 66 \\
\hline Co (ppm) & $15 \pm 4$ & $15 \pm 3$ & $18 \pm 2$ & $20 \pm 3$ & 24 & 100 & 21 & 22 & 25 & 24 \\
\hline $\mathrm{Cr}$ (ppm) & $72 \pm 8$ & $53 \pm 5$ & $78 \pm 2$ & $69 \pm 3$ & 74 & 159 & 90 & 73 & 64 & 82 \\
\hline Cs (ppm) & $5 \pm 1$ & $10 \pm 1$ & $9 \pm 0$ & $7 \pm 1$ & 6 & 8 & 5 & 4 & 6 & 10 \\
\hline Eu (ppm) & $1.1 \pm 0.1$ & $1.2 \pm 0.1$ & $1.4 \pm 0.0$ & $1.3 \pm 0.0$ & 0.9 & 1.4 & 1.2 & 1.1 & 1.2 & 1.2 \\
\hline $\mathrm{Fe}(\%)$ & $3.21 \pm 0.24$ & $3.27 \pm 0.29$ & $4.25 \pm 0.09$ & $2.91 \pm 0.14$ & 2.31 & 5.65 & 3.13 & 2.97 & 3.17 & 3.73 \\
\hline Hf (ppm) & $5 \pm 0$ & $6 \pm 1$ & $5 \pm 0$ & $6 \pm 0$ & 4 & 4 & 7 & 6 & 5 & 5 \\
\hline $\mathrm{Ni}(\mathrm{ppm})$ & $20 \pm 19$ & $15 \pm 32$ & $35 \pm 26$ & $28 \pm 26$ & 42 & 102 & 25 & 0 & 0 & 45 \\
\hline Rb (ppm) & $73 \pm 13$ & $157 \pm 19$ & $149 \pm 8$ & $162 \pm 12$ & 39 & 152 & 83 & 59 & 67 & 141 \\
\hline Rb (ppm)* & $69 \pm 14$ & $154 \pm 10$ & $148 \pm 8$ & $166 \pm 13$ & & & & & & \\
\hline $\mathrm{Sb}$ (ppm) & $3 \pm 3$ & $2 \pm 1$ & $3 \pm 0$ & $2 \pm 1$ & 1 & 1 & 1 & 1 & 3 & 1 \\
\hline Sc (ppm) & $11 \pm 1$ & $12 \pm 1$ & $16 \pm 0$ & $13 \pm 1$ & 9 & 20 & 11 & 10 & 12 & 14 \\
\hline Sr (ppm) & $455 \pm 62$ & $329 \pm 40$ & $229 \pm 33$ & $628 \pm 34$ & 531 & 180 & 420 & 569 & 255 & 685 \\
\hline Ta (ppm) & $0.9 \pm 0.1$ & $1.5 \pm 0.1$ & $1.3 \pm 0.1$ & $1.2 \pm 0.0$ & 0.8 & 1.6 & 1.1 & 0.9 & 1.0 & 1.3 \\
\hline Tb (ppm) & $0.8 \pm 0.1$ & $1.0 \pm 0.1$ & $1.0 \pm 0.1$ & $0.8 \pm 0.1$ & 0.5 & 0.8 & 0.7 & 0.7 & 0.8 & 0.8 \\
\hline Th (ppm) & $9 \pm 1$ & $15 \pm 1$ & $15 \pm 0$ & $14 \pm 0$ & 8 & 13 & 9 & 9 & 12 & 12 \\
\hline Zn (ppm) & $73 \pm 9$ & $80 \pm 8$ & $127 \pm 5$ & $68 \pm 11$ & 62 & 141 & 78 & 210 & 92 & 112 \\
\hline $\mathrm{Zr}$ (ppm) & $134 \pm 16$ & $154 \pm 21$ & $147 \pm 20$ & $165 \pm 15$ & 137 & 116 & 208 & 156 & 136 & 117 \\
\hline Al (\%) & $5.94 \pm 0.57$ & $7.77 \pm 0.56$ & $8.84 \pm 0.27$ & $7.39 \pm 0.47$ & 5.02 & 9.15 & 6.03 & 5.30 & 6.56 & 8.53 \\
\hline $\mathrm{Ba}$ (ppm) & $343 \pm 126$ & $377 \pm 35$ & $641 \pm 62$ & $544 \pm 45$ & 148 & 293 & 253 & 280 & 285 & 305 \\
\hline $\mathrm{Ba}(\mathrm{ppm}) \dagger$ & $323 \pm 38$ & & & & & & & & & \\
\hline $\mathrm{Ca}(\%)$ & $14.73 \pm 1.29$ & $13.02 \pm 0.98$ & $8.61 \pm 0.61$ & $12.05 \pm 0.71$ & 16.23 & 5.19 & 11.23 & 16.43 & 16.83 & 14.54 \\
\hline Dy (ppm) & $4 \pm 0$ & $5 \pm 0$ & $5 \pm 0$ & $5 \pm 0$ & 3 & 4 & 4 & 4 & 4 & 5 \\
\hline$K(\%)$ & $1.43 \pm 0.35$ & $2.27 \pm 0.34$ & $2.79 \pm 0.29$ & $2.76 \pm 0.23$ & 0.91 & 2.18 & 1.60 & 1.17 & 1.28 & 2.21 \\
\hline $\mathbf{K}(\%)^{\star}$ & $1.50 \pm 0.31$ & $2.33 \pm 0.23$ & $2.84 \pm 0.25$ & $2.87 \pm 0.18$ & & & & & & \\
\hline Mn (ppm) & $652 \pm 137$ & $495 \pm 29$ & $741 \pm 67$ & $336 \pm 23$ & 320 & 1105 & 380 & 547 & 542 & 225 \\
\hline $\mathrm{Na}(\%)$ & $0.65 \pm 0.19$ & $0.48 \pm 0.16$ & $0.38 \pm 0.14$ & $0.21 \pm 0.05$ & 0.72 & 0.52 & 0.62 & 0.65 & 0.61 & 0.29 \\
\hline $\mathrm{Na}(\%)^{*}$ & $0.62 \pm 0.19$ & $0.43 \pm 0.05$ & $0.34 \pm 0.04$ & $0.19 \pm 0.03$ & & & & & & \\
\hline $\mathrm{Ti}(\%)$ & $0.34 \pm 0.03$ & $0.35 \pm 0.03$ & $0.41 \pm 0.02$ & $0.40 \pm 0.03$ & 0.23 & 0.47 & 0.32 & 0.32 & 0.34 & 0.37 \\
\hline V (ppm) & $82 \pm 12$ & $68 \pm 5$ & $119 \pm 10$ & $79 \pm 7$ & 76 & 132 & 88 & 85 & 88 & 90 \\
\hline
\end{tabular}

$4 \underline{3}$ Values for those groups without taking into account samples showing analcime in their diffractograms $t=B a$ values for those groups which include samples with aberrant $\mathrm{Ba}$ contents 
Table 4. Mean and standard deviation of the 208 majolica sherds from the main production centers of the Iberian Peninsula and the reception centers of the Canary Islands according to the different chemical groups identified by INAA. All values are expressed as ppm ( $\mu \mathrm{g} / \mathrm{g})$ except those expressed as weight $\%$ in brackets. $*$ Values for those groups without taking into account samples showing analcime in their diffractograms. $\dagger$ Ba values for those groups which include samples with aberrant Ba contents 
Membership Probabilities (\%) Best Group Suggested Provenance

$\begin{array}{lccccc}\text { ANID } & \text { Manises } & \text { Talavera } & \text { Sevilla } & & \\ \text { MJ0236 } & \mathbf{5 . 1 0} & 0.27 & 0.03 & \text { Manises } & \text { Manises } \\ \text { MJ0237 } & 0.01 & 0.06 & \mathbf{6 4 . 5 6} & \text { Sevilla } & \text { Sevilla } \\ \text { MJ0241 } & 0.04 & 0.12 & \mathbf{6 0 . 3 4} & \text { Sevilla } & \text { Sevilla } \\ \text { MJ0253 } & 0.01 & 0.02 & \mathbf{5 8 . 7 9} & \text { Sevilla } & \text { Sevilla } \\ \text { MJ0258 } & 0.03 & 0.26 & \mathbf{9 8 . 0 7} & \text { Sevilla } & \text { Sevilla } \\ \text { MJ0262 } & 0.13 & 0.10 & \mathbf{7 . 0 6} & \text { Sevilla } & \text { Sevilla } \\ \text { MJ0268 } & 0.02 & 0.08 & \mathbf{9 7 . 8 3} & \text { Sevilla } & \text { Sevilla } \\ \text { MJ0269 } & 0.00 & 0.04 & 0.30 & - & \text { Delft (?) } \\ \text { MJ0270 } & 0.00 & 0.00 & 0.00 & - & \text { Ligur } \\ \text { MJ0272 } & 0.00 & 0.00 & 0.00 & - & \text { Ligur } \\ \text { MJ0275 } & 0.18 & 0.00 & 0.00 & - & \text { Portugal } \\ \text { MJ0284 } & 0.01 & 0.00 & 0.00 & - & \text { Italy (?) } \\ \text { MJ0285 } & \mathbf{1 0 . 8 6} & 1.26 & 0.02 & \text { Manises } & \text { Manises } \\ \text { MJ0286 } & 0.01 & 0.04 & \mathbf{1 4 . 2 1} & \text { Sevilla } & \text { Sevilla } \\ \text { MJ0287 } & 0.03 & 0.04 & 0.11 & - & \text { Unassigned } \\ \text { MJ0288 } & 0.00 & 0.01 & 0.00 & - & \text { Unassigned } \\ \text { MJ0289 } & 0.03 & 0.09 & \mathbf{3 . 8 1} & \text { Sevilla } & \text { Sevilla } \\ \text { MJ0290 } & 0.00 & 0.00 & 0.00 & - & \text { Ligur } \\ \text { MJ0291 } & 0.00 & 0.00 & 0.00 & - & \text { Ligur } \\ \text { MJ0292 } & 0.05 & 0.00 & 0.00 & - & \text { Portugal } \\ \text { MJ0293 } & \mathbf{3 9 . 6 5} & 0.60 & 0.01 & - & \text { BCN-SC* } \\ \text { MJ0294 } & 0.12 & 0.00 & 0.00 & - & \text { Unassigned }\end{array}$


Table 5. Membership probabilities in percentage and suggested provenance according to Mahalanobis Distance calculations, Discriminant analysis and scatter plots. *Although MJ0293 has high membership probability of belonging to the Manises group, it clearly has membership in BCN-SC (see Figures 4 and 5) 